Prepared for the U.S. Department of Energy

under Contract DE-AC05-76RL01830

\title{
Second Line of Defense Spares Program Assessment
}

\author{
DL Henderson RT Brigantic \\ G Muller \\ CJ Perkins \\ TM Mercier \\ SK Cooley
}

November 2012

Pacific Northwest

NATIONAL LABORATORY

Proudly Operated by Battelle Since 1965 


\title{
DISCLAIMER
}

This report was prepared as an account of work sponsored by an agency of the United States Government. Neither the United States Government nor any agency thereof, nor Battelle Memorial Institute, nor any of their employees, makes any warranty, express or implied, or assumes any legal liability or responsibility for the accu racy, completeness, or usefulness of any information, apparatus, product, or process disclosed, or represents that its use would not infringe privately owned rights. Reference herein to any specific commercial product, process, or service by trade name, trademark, manufacturer, or otherwise does not necessarily constitute or imply its endorsement, recommendation, or favoring by the United States Government or any agency thereof, or Battelle Memorial Institute. The views and opinions of authors expressed herein do not necessarily state or reflect those of the United States Government or any agency thereof.

\section{PACIFIC NORTHWEST NATIONAL LABORATORY \\ operated by \\ BATTELLE \\ for the \\ UNITED STATES DEPARTMENT OF ENERGY \\ under Contract DE-AC05-76RL01830}

Printed in the United States of America

$$
\begin{aligned}
& \text { Available to DOE and DOE contractors from the } \\
& \text { Office of Scientific and Technical Information, } \\
& \text { P.O. Box 62, Oak Ridge, TN } 37831-0062 ; \\
& \text { ph: }(865) 576-8401 \\
& \text { fax: }(865) 576-5728 \\
& \text { email: reports@adonis.osti.gov }
\end{aligned}
$$

\author{
Available to the public from the National Technical Information Service \\ 5301 Shawnee Rd., Alexandria, VA 22312 \\ ph: (800) 553-NTIS (6847) \\ email: orders@ntis.gov <http://www.ntis.gov/about/form.aspx> \\ Online ordering: http://www.ntis.gov
}


PNNL-22026

\title{
Second Line of Defense Spares Program Assessment
}

\author{
DL Henderson RT Brigantic \\ G Muller \\ CJ Perkins \\ TM Mercier \\ SK Cooley
}

November 2012

Prepared for

the U.S. Department of Energy

under Contract DE-AC05-76RL01830

Pacific Northwest National Laboratory

Richland, Washington 99352 



\section{Summary}

The Office of the Second Line of Defense (SLD) is part of the Department of Energy's (DOE) National Nuclear Security Administration (NNSA). The SLD Program accomplishes its critical global security mission by forming cooperative relationships with partner countries to install passive radiation detection systems that augment traditional inspection and law enforcement measures by alerting border officials to the presence of special nuclear or other radiological materials in cross-border traffic. An important tenet of the program is to work collaboratively with these countries to establish the necessary processes, procedures, infrastructure and conditions that will enable them to fully assume the financial and technical responsibilities for operating the equipment.

As the number of operational deployments grows, the SLD Program faces an increasingly complex logistics process to promote the timely and efficient supply of spare parts. The Pacific Northwest National Laboratory (PNNL) has been designated by DOE-SLD to work closely with partner countries to jointly develop sustainability plans that are designed to ensure installed radiation detection systems remain effective not only throughout the sustainability period but also once partner countries assume full responsibility for the performance of the systems.

In support of these goals, PNNL has undertaken a holistic study of the existing SLD spares system with the goal of providing both an assessment of the current spares processes and concrete recommendations for program improvement based on thorough analysis. Assessment is one of three phases of the study, which also includes the Analysis and Program Development phases. This report describes the assessment effort conducted under this comprehensive spares study for the SLD Sustainability program.

The assessment was conducted in three major components of effort and offers a recommended way forward in two overarching functional categories. The first major component of the assessment was a broad information gathering effort including interviews and interactions with staff who manage and execute the sustainability functions. The second component was a discovery and survey of the existing data repositories where information relevant to spares analysis has been collected either as historical records or as operational or management documentation. The third component was a systematic assessment and description of relevant stakeholders, system functions, and lifecycle considerations.

The recommended way forward from this assessment is to conduct analyses aimed at enabling improvements to existing procedures and/or the implementation of new program alternatives in two broad categories. The first of these is in the way information is gathered, transmitted, stored, retrieved, and used to make decisions not only about spares, but also more generally about maintenance, and for use in assessment metrics. The second area is physical material handling, acquisition, transportation, and stocking. This includes analyzing, categorizing, and documenting the conditions under which tailored inventories should be managed at various levels in a more clearly defined supply chain. 



\section{Contents}

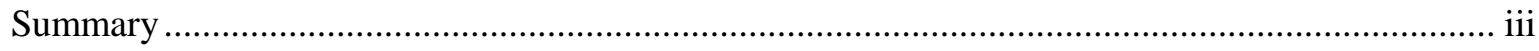

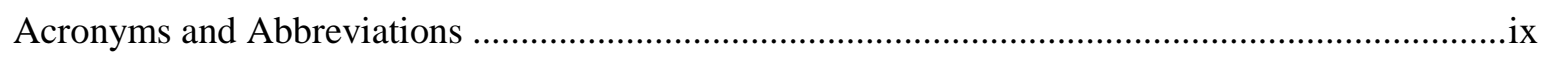

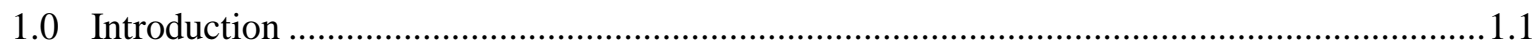

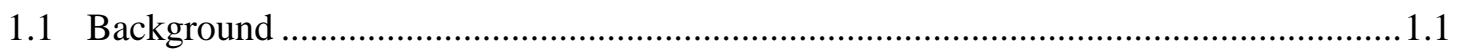

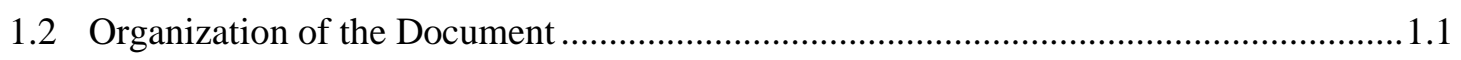

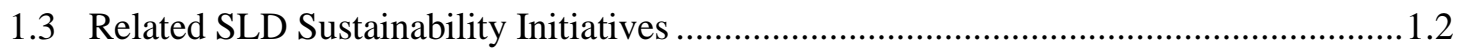

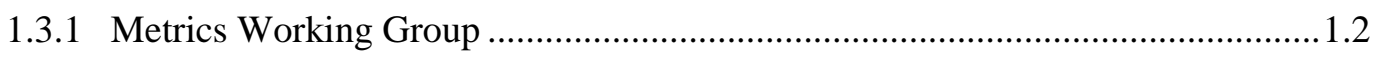

1.3.2 Maintenance Working Group ..................................................................... 1.2

1.3.3 Configuration Items Working Group ............................................................. 1.2

1.3.4 Help Desk Deep Dive......................................................................................

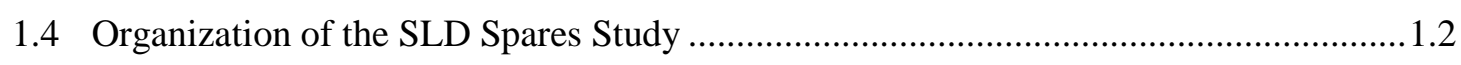

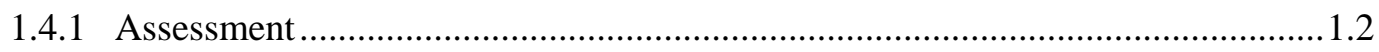

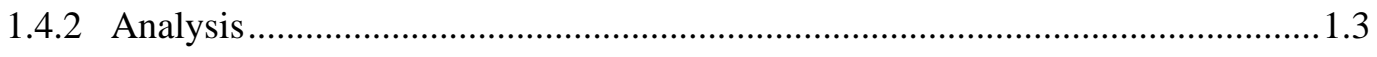

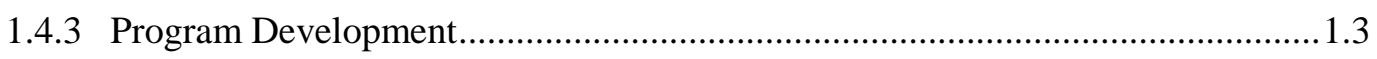

1.5 Overview of Observations and Recommendations ..........................................................

1.5.1 Assessment of Information and Data Management..............................................

1.5.2 Assessment of Resource Management and Material Handling ............................1.4

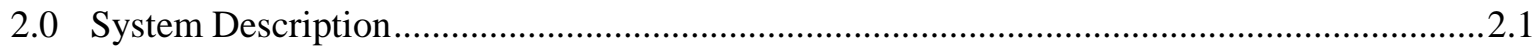

2.1 SLD Radiation Detection System Physical Breakdown...............................................2.1

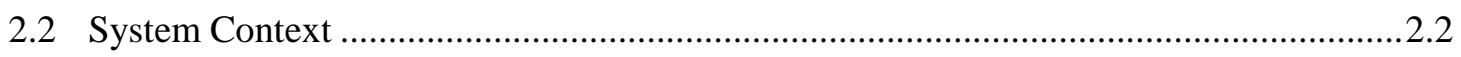

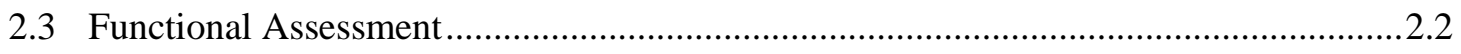

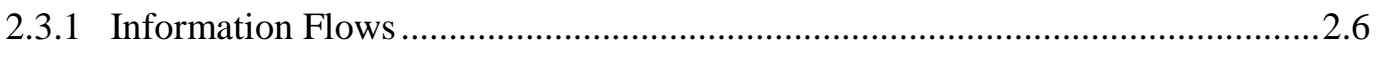

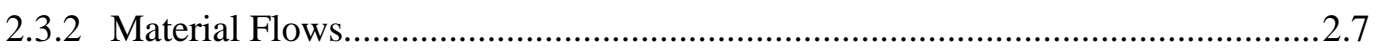

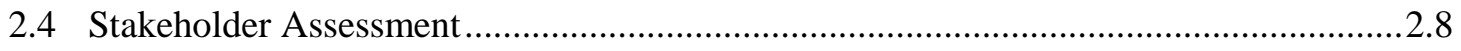

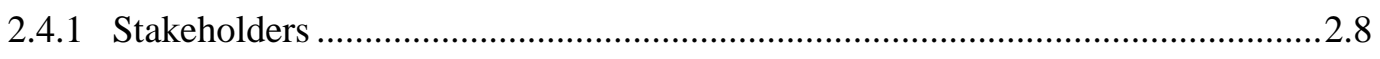

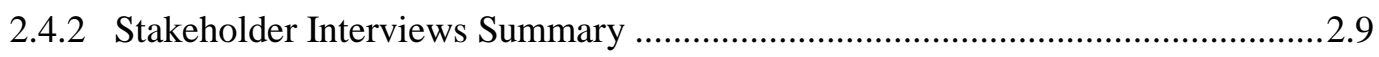

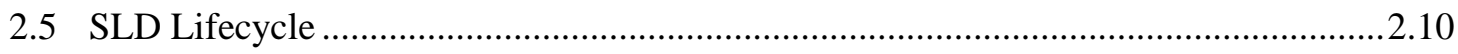

2.5.1 Country Engagement................................................................................... 2.12

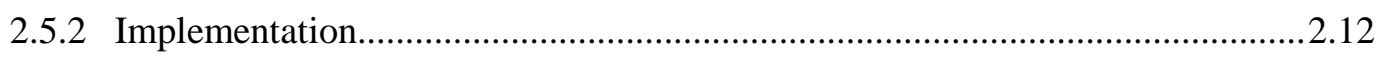

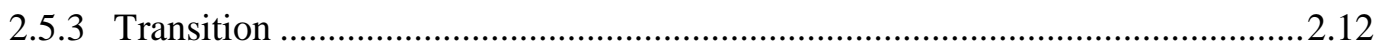

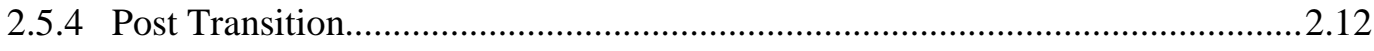

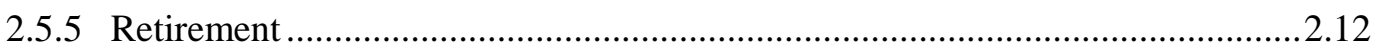

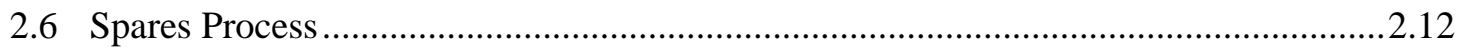

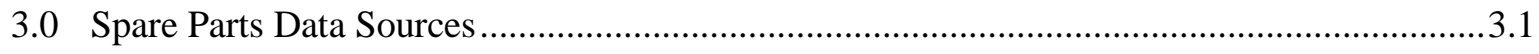

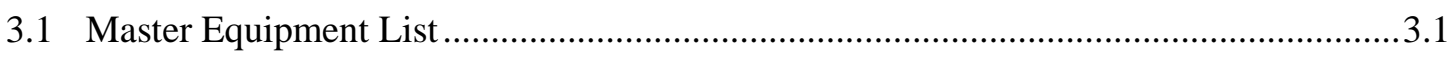

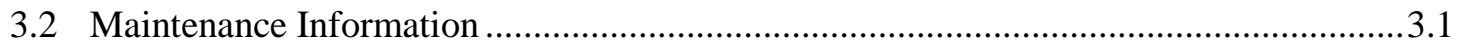




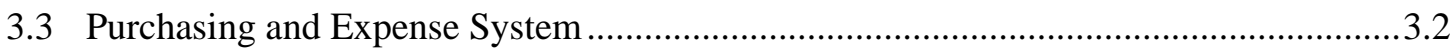

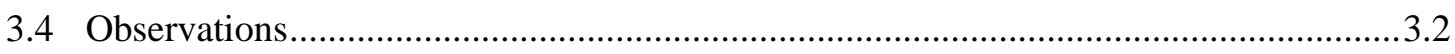

3.5 Limited List of Parts for TSA and Aspect RPMs............................................................

4.0 Preliminary Findings and Recommendations ................................................................ 4.1

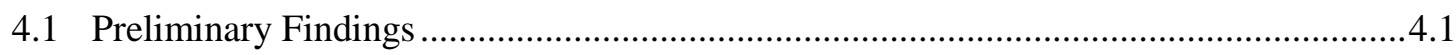

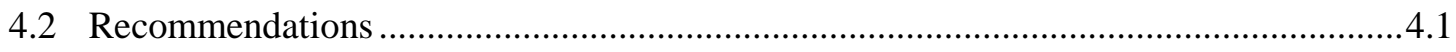

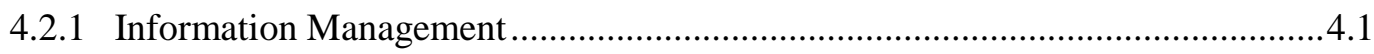

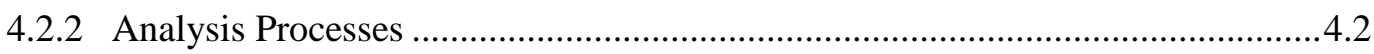

4.2.3 Material Management …............................................................................... 4.2

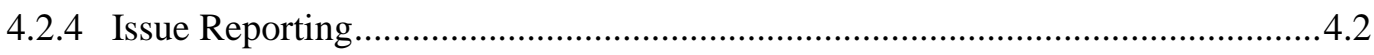

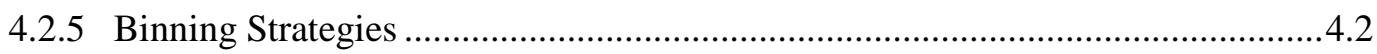

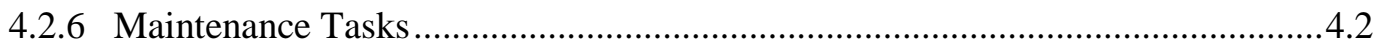

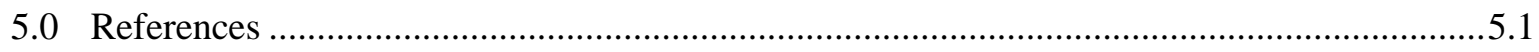

Appendix A - Stakeholder Interviews ................................................................................. A. 1

Appendix B - System Datasets and Parts Listings ...................................................................... B.1 


\section{Figures and Tables}

\section{Figures}

Figure 2.1. Physical Architecture of the SLD Detection System.................................................2.2

Figure 2.2. Information Flows in the SLD Sustainability Program .............................................2.7

Figure 2.3. Material Flows in the SLD Sustainability Program...................................................2.8

Figure 2.4. SLD Site Lifecycle ......................................................................................... 2.11

Figure 2.5. SLD Detection System Lifecycle: Site Histogram ................................................2.11

\section{Tables}

Table 2.1. SLD Spares Functional Decomposition.....................................................................

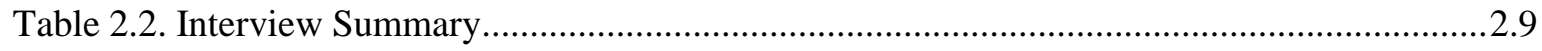





\section{Acronyms and Abbreviations}

DICCE Design, integration, construction, communications, and engineering

DOE U.S. Department of Energy

LMP local maintenance provider

NNSA National Nuclear Security Administration

PES Purchasing and Expense System

PNNL Pacific Northwest National Laboratory

RPM radiation portal monitors

SLD Second Line of Defense

TSA Transportation Security Administration

VAT value-added tax 



\subsection{Introduction}

\subsection{Background}

The Office of the Second Line of Defense (SLD) is part of the Department of Energy's (DOE) National Nuclear Security Administration (NNSA). The SLD Program accomplishes its critical global security mission by forming cooperative relationships with partner countries to install passive radiation detection systems that augment traditional inspection and law enforcement measures by alerting border officials to the presence of special nuclear or other radiological materials in cross-border traffic. Important tenets of the program include transitioning the systems to partner countries to facilitate long-term sustainability and operation of radiation detection systems. This is accomplished by working collaboratively with these countries to establish the necessary processes, procedures, infrastructure, and conditions that will enable them to fully assume the financial and technical responsibilities for operating the equipment.

The equipment is required to operate continuously, often at remote locations with diminished infrastructure. In order to promote maximum operational availability, there must be maintenance competency and a commensurate inventory of spare parts and consumables. As the number of operational deployments grows, the SLD Program faces an increasingly complex logistics process to assure the timely and efficient supply of spare parts.

The Pacific Northwest National Laboratory (PNNL) has been designated by DOE-SLD to work closely with partner countries to jointly develop sustainability plans that are designed to ensure installed radiation detection systems remain effective not only throughout the sustainability period but also once partner countries assume full responsibility for the performance of the systems.

In support of these goals, PNNL has undertaken a holistic study of the existing SLD spares system with the goal of providing both an assessment of the current spares processes and concrete recommendations for program improvement based on thorough analysis. The SLD spares study team is composed of members of the Applied Statistics and Computational Modeling Group at PNNL, working in close partnership with the entire SLD Sustainability community. Collectively, the team has expertise in systems engineering, operations research, supply chain management, maintenance logistics, data analysis, and statistics.

\subsection{Organization of the Document}

This document is organized into four main sections. Section 1 provides background information. Section 2 is a description of the spares system, its context, functions, stakeholders, lifecycle, and existing design. Section 3 is a description of the data environment including the systems used to collect and store data and the scope, quality, and potential of existing data repositories. Section 4 provides preliminary findings and detailed recommendations for further analysis and program development. Raw interview notes are provided in Appendix A and detailed information about the data repositories is in Appendix B.

This paper documents the findings of the assessment phase of the study and proposes an approach to further analysis in support of the development of changes and new solutions across the span of SLD spares program functions. 


\subsection{Related SLD Sustainability Initiatives}

In parallel with the spares study, SLD Sustainability has tasked several working groups that are closely related to the spares system. The spares study will coordinate pertinent activities with these working groups.

\subsubsection{Metrics Working Group}

The Metrics Working Group is tasked with constructing a set of clearly defined sustainability metrics. These metrics serve a critical purpose in providing decision makers with an understanding of how well the SLD systems perform the specified mission. An SLD spares program serves a supporting role for the overall program objectives captured in these metrics.

\subsubsection{Maintenance Working Group}

The Maintenance Working Group is tasked with developing maintenance packages focused on the radiation detection subsystems, including development of functional descriptions and functional failure definitions. These products will be used to design and develop a set of maintenance work packages that the local maintenance provider (LMP) will be expected to follow.

\subsubsection{Configuration Items Working Group}

The Configuration Items Working Group is tasked with creating clearly defined and categorized item lists to enable more consistent inventory tracking, reporting, and logistics management across the sustainability system. The SLD spares program will use the products of this working group to develop, formalize, and implement the approach to manage these configuration items.

\subsubsection{Help Desk Deep Dive}

The Help Desk Deep Dive initiative seeks to develop a set of actionable specific recommendations, supported by SLD Help Desk data, to improve the operational performance, reliability, and sustainability of the SLD radiation detection system while reducing costs.

\subsection{Organization of the SLD Spares Study}

The spares study commenced in late January 2012 and will be completed by the end of Fiscal Year 2012. The study is organized into three phases: assessment, analysis, and program development.

\subsubsection{Assessment}

The assessment phase culminated with the delivery of this report. The goals of the assessment phase were to build a clear understanding of the SLD Sustainability program with emphasis on those components of the system that impose requirements and constraints on spares strategy and procedures. The report identifies the technical, organizational, staffing, and other general capabilities that are currently employed to maintain SLD-provided systems. The assessment includes discussion of:

- Maintenance requirements and procedures for the SLD equipment deployed to partner countries (preventive and corrective maintenance)

- A functional analysis of the management of a spares program, including application to SLD detection system lifecycle phases 
- A general assessment of the capability of LMPs to execute these maintenance procedures, especially as capabilities impact the ability of LMPs to perform tasks associated with spares management

- Data discovery and analysis of spares records, and an evaluation of critical parts necessary to support maintenance actions

- Capabilities and current practices of LMPs in parts sourcing and procurement.

The functional assessment for a spares program is described in Section 2.3. These functions form the basis from which existing approaches to spares management are assessed.

A significant component of the assessment is a series of interviews with stakeholders from a range of positions within the SLD Sustainability organization. These interviews included sustainability managers, project managers, contracting, maintenance, administrative, and information management personnel from NNSA and national laboratories. Stakeholder considerations from outside this group, most importantly those of the LMPs and site operators, were identified in the sustainability manager interviews, but no foreign personnel were directly interviewed. These interviews are summarized in Section 2 and raw interview notes are collated in Appendix A. In addition, stakeholder context was gained though exposure to general knowledge about program history as the team worked with a host of SLD Sustainability personnel in teleconferences, on various working groups, and at the March Best Practices Workshop. The spares study team has developed close working relationships with many experienced SLD Sustainability hands.

A third significant component of the assessment is the discovery and exploration of the existing SLD Sustainability data repositories described in Section 3.

\subsubsection{Analysis}

The analysis phase will implement the way forward proposed in this paper with the goal of producing an analytic framework, organizing existing data, and creating models sufficient to clearly quantify the impact on the SLD system of various proposed modifications and the application of new solutions to the spares program. This analysis will support decision making about the selection of potential solutions for implementation in the program development phase.

\subsubsection{Program Development}

The program development phase will build the documentation, information system designs, and other information products necessary to implement changes in existing procedures or apply new solutions in the spares program.

\subsection{Overview of Observations and Recommendations}

The SLD Program, and the SLD Sustainability component in particular, is a continuously evolving a combination of skills, tools, and techniques:

Organization. Over the life of the SLD Program, the organization structure has evolved in ways that include changes and realignment of partnerships and responsibilities among government, partner country, and national laboratory partners. Currently responsibility for sustainability is consolidated at the NNSA SLD Sustainability Program. Execution of sustainability functions is carried out in partnership with national laboratories and LMPs in partner countries. 
Technology. The current fleet of installed radiation detection equipment represents over a decade of evolutionary improvement in capability and reliability enhancements. Lessons learned from the initial deployments of this equipment have been incorporated into new system and component designs as well as better maintenance and operational procedures.

Policy. With respect to both sustainability and design/build contracting, the implementation of SLD sites, training, management, and maintenance have all evolved over the life of the program in response to feedback, emerging requirements, and a robust lessons learned process along with an information sharing culture.

Procedure. The documented procedures and best practices under which actions are carried out have seen continuous evolution and improvement, especially in regards to maintenance, training, assurance, and sustainability contracting.

Classic supply chain management principles, for example as discussed in Hugos (2003), are applicable to the SLD Program only insofar as the program can access and use information, enforce the application of standardized procedures, and build competency among all of the partners with a role in operating a spares system.

\subsubsection{Assessment of Information and Data Management}

Our assessment of the information and data environment relating to spares management is aimed at:

- Enumerating the formal and informal information pathways in current use

- Determining which of these pathways are of potential use in a formal spares management process

- Cataloging the data repositories into which information about maintenance and spares is collected

- Evaluating the contents, periods of coverage, and quality of these data repositories.

The overall assessment is that general sustainability information management, including information about maintenance activities and spares, is collected and distributed in too much of an ad hoc manner that does not permit effective centralized visibility of the status of spares throughout the program. Without this visibility, the spares program will be forced to operate in a distributed fashion with each sustainability manager responsible for building their own standalone system.

During the analysis and program design phases of this study, we recommend examining alternatives for enhancing the current sustainability data environment and related processes in order to facilitate a host of program functions. From this assessment we have an understanding of the existing limitations and constraints that currently prohibit centralized management of all aspects of sustainability and recommend solutions designed to maintain decentralized execution while providing value to all stakeholders through more complete visibility. This will enable centralized management and oversight of the overall spares management process, resulting in greater transparency of the process and better enabling post-transition operation.

\subsubsection{Assessment of Resource Management and Material Handling}

Our analysis of the spares material will clarify and detail the role for an SLD spares program by:

- Enumerating parts that are currently in the spares system

- Associating parts with an individual maintenance action (repair, replacement, or preventative) 
- Cataloging locations where spares and related materials are currently stored or handled

- Classifying parts in terms of maintenance function, cost, and other factors

- Identifying that subset of inventory that should be managed formally in a spares program (e.g., controlled spares).

The primary recommendation for a way forward with respect to material inventories and handling is to first construct the most comprehensive component listing possible given existing information (including informal information from maintenance subject matter experts and sustainability managers). This list will be the basis for an application of conventional supply chain analysis tailored to the unique constraints of the SLD system. Spares stock items should be classified by criticality. Several categories of spares are outlined in Nymann and Levitt (2001).

Insurance spares. High-cost spares or components used on critical equipment. These items have high costs, long-lead times, and whose loss can lead to major losses of production.

Insurance parts. Parts used on critical equipment or in critical components. Failures are unpredictable and they are carried in inventory under tight control.

Standard replacement parts. Parts that can be used on more than one component or piece of equipment, for example hard drives, computer monitors, and similar information technology components.

Hardware items. Items that have low unit costs and are readily available from suppliers (e.g., bolts, nuts, washers, and other fasteners).

Operating chemicals and supplies. Consumable items used in the operation of a detector system (e.g. desiccant for radiation portal monitors (RPMs)).

General supplies. General supplies not used in the operation of the system (e.g., office, cleaning, and sanitary supplies).

Of the categories above, formal spares program procedures should focus on insurance spares and insurance parts. An example of an insurance spare would be an entire portal assembly held in inventory at some intermediate location against the possibility of a catastrophic failure or mishap at a site. In addition to these categories, Nymann and Levitt (2001) also suggest an $A B C$ or Pareto analysis to categorize parts as:

A Items. Items of highest value, under tightest control, with close follow up and requiring accurate records (e.g., insurance spares and parts).

B Items. Items under normal control with good records (e.g., standard replacement parts).

C Items. Items under limited control and held in free stock (e.g., records not tied to a particular work order).

During the Analysis and Program Development phases of this study, we recommend building out a uniform set of spares lists from the available data and applying a consistent set of criteria to categorize the items on these lists in the terms described here. We advocate the development of a living spares list that is continuously modified to reflect ongoing process changes, technology upgrades, and operational needs. 



\subsection{System Description}

The SLD Program serves the radiation detection needs for cargo at maritime ports (via Megaports) and cargo, vehicle, and passenger traffic at land border crossings (via Core). Site selection, design, and development take into account the widely varying needs, constraints, and requirements for deploying SLD radiation detection systems across these foreign cargo terminals and land border crossings. These site-specific requirements dictate the configuration and equipment deployed to support SLD detection systems. In turn, the deployed technologies, in combination with site operational considerations and environmental variables, dictate the support, maintenance, parts, and sparing requirements to enable system operation.

The SLD Program has deployed a total of 293 Core and Megaports sites across 62 countries ${ }^{1}$. The complexity of managing an international system of radiation detection equipment, deployed in key international trade and cargo hubs as well as remote land border crossings, requires meticulous balancing of stakeholder relationships with adherence to operating requirements, parts logistics, and contract management between partner countries, operators, and maintainers.

\subsection{SLD Radiation Detection System Physical Breakdown}

Equipment is deployed to SLD Core and Megaports sites based on a number of constraints, requirements, and programmatic and design decisions. Figure 2.1 presents one way in which the system can logically be refined into subsystems and components. A physical breakdown provides a common, standardized way of communicating about the system, and allows traceability of parts, spares, components, and subsystems to site deployment configuration. This is important to support inventory management, preventive and corrective maintenance, and development of maintenance packages for LMPs to follow.

\footnotetext{
${ }^{1}$ Data summarized from Q1 FY2012 Spotlight Report
} 


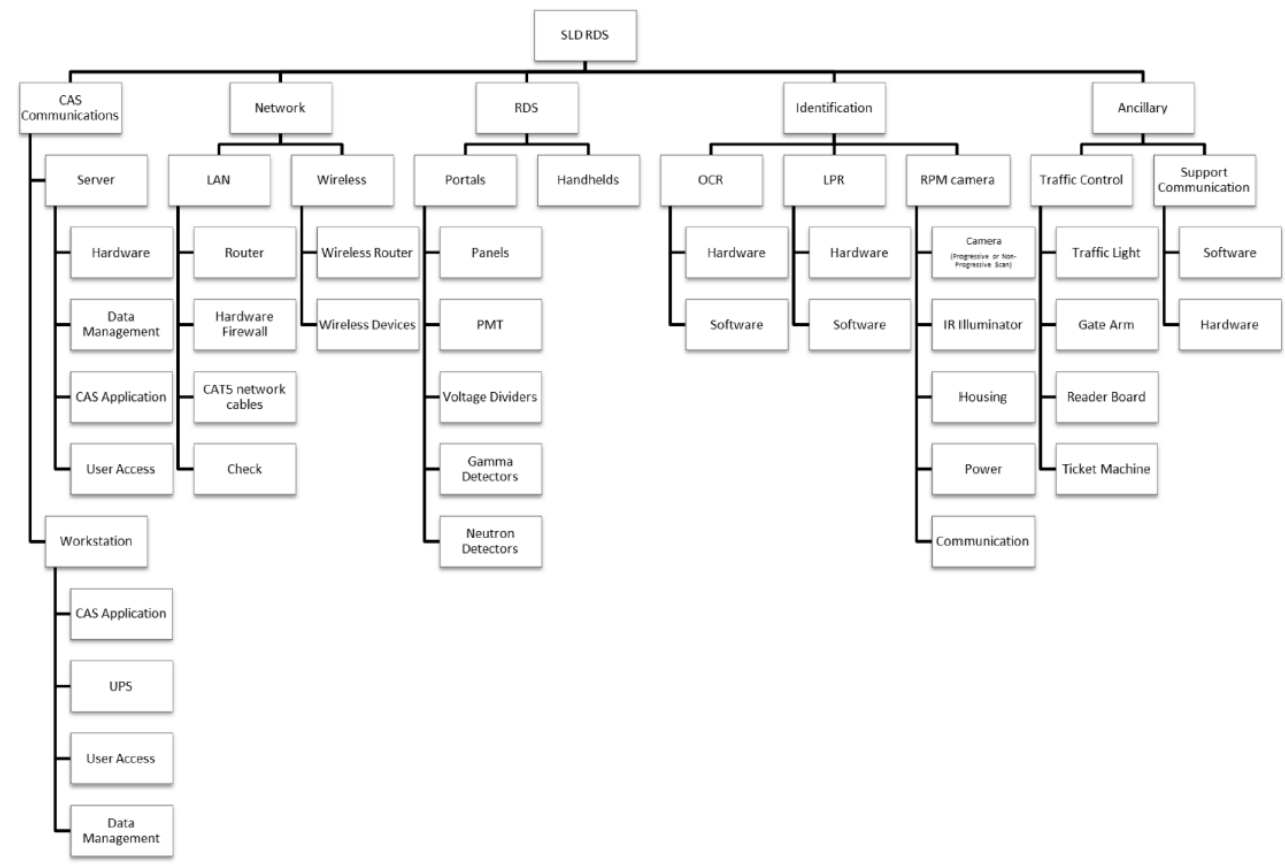

Figure 2.1. Physical Architecture of the SLD Detection System

\subsection{System Context}

The SLD Program exists to obtain partner country engagement in the global effort to detect radiological and nuclear material that strays outside of regulatory control. The spares program exists so that SLD detection systems are in operation and available to serve the detection function. A successful spares program ensures that the right parts are in the right place at the right time in a cost-effective and efficient manner. This program requires a clear definition of the people, processes, and resources necessary to implement a spares strategy. Current sparing efforts consist of:

- Initial spares inventory (for a site, managed by an LMP)

- Reporting processes for corrective maintenance

- Reordering steps that require coordination of multiple parties/stakeholders

- Parts delivery system for replenishment

- Information feedback mechanism to the LMP.

\subsection{Functional Assessment}

SLD Sustainability requires a spares program that effectively coordinates handling information and material to support design, deployment, sustainment, and transition of the SLD radiation detection systems; improves system performance; and remains within cost constraints. In order to manage the SLD spares program, the organization must be capable of performing two overarching functions from which all other necessary sub-functions are derived: 
Each sub-function within the functional breakdown exists to support the goals of the parent function. All functions defined ultimately support these two top-level functions. The functional breakdown for the SLD spares program is presented in Table 2.1 with the corresponding goals defined for each function.

Manage information. To allow the flow of information to inform how and when materials move and dictate how available information can be used to support analyses of system performance.

Operational information. To manage the routine information necessary to operate and maintain SLD radiation detection systems. This includes information exchange between the design, integration, construction, communications, and engineering (DICCE) contractors, site personnel and operators, LMP, sustainability and country managers, Help Desk, and contracts representatives to support resource and material management for those tasks required to keep the system operational.

Information for analysis. To understand how the system operates and how well it performs against selected measures. This information is used to drive decisions that allow the system to perform more efficiently and effectively. Currently, available information is used to conduct program analyses in the form of periodic reports and ad hoc inquiries. Routine analytic processes will leverage available data sources and adhere to the programmatic, operational, and technological constraints present in the program.

Managing resources. Provides the necessary mechanism for the system to operate and perform the intended function according to program objectives and specified performance requirements.

Inventory management. Provides a means to store, secure, protect, and account for spares used for the maintenance of SLD detection systems.

Repair parts (spares). Must be supplied, provisioned, and delivered in order to maintain deployed systems. Key to the success of a spares strategy is the long-term viability of the provisioning and distribution mechanisms used within the system, especially those involving the LMP post transition.

Consumables. Must be present at the point of use. Given a site's design, environmental considerations, and preventive maintenance schedule, the consumption of consumables can be planned for accordingly.

Disposition of worn or damaged components. Important and may be needed to support analysis. A parts disposition plan is an element of a spares strategy and must coordinate with the analysis efforts that rely on information available from these parts and with with LMPs to sustain the disposition plan post transition.

Table 2.1. SLD Spares Functional Decomposition

\begin{tabular}{|c|c|c|c|c|c|}
\hline Level 1 & Level 2 & Level 3 & Level 4 & Level 5 & Goal \\
\hline \multicolumn{6}{|c|}{$\begin{array}{l}\text { Manage SLD } \\
\text { spares program }\end{array}$} \\
\hline & $\begin{array}{l}\text { Manage } \\
\text { information }\end{array}$ & & & & \\
\hline & & $\begin{array}{l}\text { Manage } \\
\text { operational } \\
\text { information }\end{array}$ & & & \\
\hline & & & $\begin{array}{l}\text { Report part } \\
\text { failure }\end{array}$ & & Initiate part replacement \\
\hline & & & Submit an order & & $\begin{array}{l}\text { Obtain part from source, enable } \\
\text { data collection }\end{array}$ \\
\hline
\end{tabular}




\begin{tabular}{|c|c|c|c|c|c|}
\hline \multirow[t]{19}{*}{ Level 1} & Level 2 & Level 3 & Level 4 & Level 5 & Goal \\
\hline & & & $\begin{array}{l}\text { Report an } \\
\text { inventory status }\end{array}$ & & $\begin{array}{l}\text { Enable data collection, permit } \\
\text { planning and management, } \\
\text { regularity/consistency }\end{array}$ \\
\hline & & & $\begin{array}{l}\text { Report } \\
\text { maintenance } \\
\text { status }\end{array}$ & & $\begin{array}{l}\text { Provide system information, } \\
\text { regularity/ consistency }\end{array}$ \\
\hline & & & Source a part & & $\begin{array}{l}\text { Obtain a replacement part, } \\
\text { continue system operation }\end{array}$ \\
\hline & & & $\begin{array}{l}\text { Report } \\
\text { disposition (close } \\
\text { out) }\end{array}$ & & $\begin{array}{l}\text { Enforce standards, keep data } \\
\text { clean, inform management }\end{array}$ \\
\hline & & & $\begin{array}{l}\text { Communicate } \\
\text { lessons and } \\
\text { trends }\end{array}$ & & $\begin{array}{l}\text { Improve overall system } \\
\text { performance }\end{array}$ \\
\hline & & $\begin{array}{l}\text { Manage } \\
\text { information for } \\
\text { analysis }\end{array}$ & & & \\
\hline & & & Collect data & & $\begin{array}{l}\text { Collect necessary data as much, } \\
\text { consistently, accurately, } \\
\text { persistently }\end{array}$ \\
\hline & & & & $\begin{array}{l}\text { Establish } \\
\text { process }\end{array}$ & $\begin{array}{l}\text { Execute a standardized, } \\
\text { measurable approach }\end{array}$ \\
\hline & & & & Enable input & $\begin{array}{l}\text { Minimize manual entry (i.e., } \\
\text { computer automated entries, } \\
\text { selectable error codes) }\end{array}$ \\
\hline & & & & Enable output & $\begin{array}{l}\text { Use data to inform business } \\
\text { decisions }\end{array}$ \\
\hline & & & & $\begin{array}{l}\text { Maintain } \\
\text { process }\end{array}$ & $\begin{array}{l}\text { Sustain the process by making } \\
\text { it user friendly and repeatable }\end{array}$ \\
\hline & & & $\begin{array}{l}\text { Identify full parts } \\
\text { list for each } \\
\text { system and at } \\
\text { each location } \\
\text { within country }\end{array}$ & & $\begin{array}{l}\text { Implement parts traceability } \\
\text { and accountability, manage } \\
\text { inventory }\end{array}$ \\
\hline & & & $\begin{array}{l}\text { Set initial } \\
\text { inventory } \\
\text { (location, } \\
\text { quantity) }\end{array}$ & & Operate cost effectively \\
\hline & & & Set order points & & $\begin{array}{l}\text { Set points that minimize stock } \\
\text { outs and inventory costs, and } \\
\text { align with program objectives }\end{array}$ \\
\hline & & & $\begin{array}{l}\text { Set parts } \\
\text { sourcing strategy }\end{array}$ & & $\begin{array}{l}\text { Obtain parts reliably, cost } \\
\text { effectively, and timely }\end{array}$ \\
\hline & & & $\begin{array}{l}\text { Set parts delivery } \\
\text { strategy }\end{array}$ & & $\begin{array}{l}\text { Timely parts availability while } \\
\text { minimizing costs }\end{array}$ \\
\hline & & & $\begin{array}{l}\text { Set parts } \\
\text { disposition } \\
\text { strategy }\end{array}$ & & $\begin{array}{l}\text { Economical, analysis needs, } \\
\text { environmental impact }\end{array}$ \\
\hline & & & $\begin{array}{l}\text { Identify changes } \\
\text { to roles and } \\
\text { relationships }\end{array}$ & & $\begin{array}{l}\text { Execute a sustainable, } \\
\text { repeatable approach }\end{array}$ \\
\hline
\end{tabular}




\begin{tabular}{|c|c|c|c|c|c|}
\hline Level 1 & Level 2 & Level 3 & Level 4 & Level 5 & Goal \\
\hline & & & $\begin{array}{l}\text { Maintain process } \\
\text { control and } \\
\text { analysis process }\end{array}$ & & $\begin{array}{l}\text { Implement reliability and } \\
\text { process control measures to } \\
\text { assess performance }\end{array}$ \\
\hline & & & & $\begin{array}{l}\text { Establish } \\
\text { reliability } \\
\text { measures }\end{array}$ & $\begin{array}{l}\text { Ensure reliable system, identify } \\
\text { impactful root causes }\end{array}$ \\
\hline & & & & $\begin{array}{l}\text { Identify } \\
\text { leading causes } \\
\text { of failure }\end{array}$ & $\begin{array}{l}\text { Identify leading failures - } \\
\text { Pareto analysis }\end{array}$ \\
\hline & & & & $\begin{array}{l}\text { Establish } \\
\text { control limits }\end{array}$ & $\begin{array}{l}\text { Understand system } \\
\text { performance - statistical } \\
\text { process control }\end{array}$ \\
\hline & & & $\begin{array}{l}\text { Identify lessons } \\
\text { and trends, } \\
\text { symptoms, root } \\
\text { causes }\end{array}$ & & $\begin{array}{l}\text { Early identification to inform } \\
\text { business decisions }\end{array}$ \\
\hline
\end{tabular}

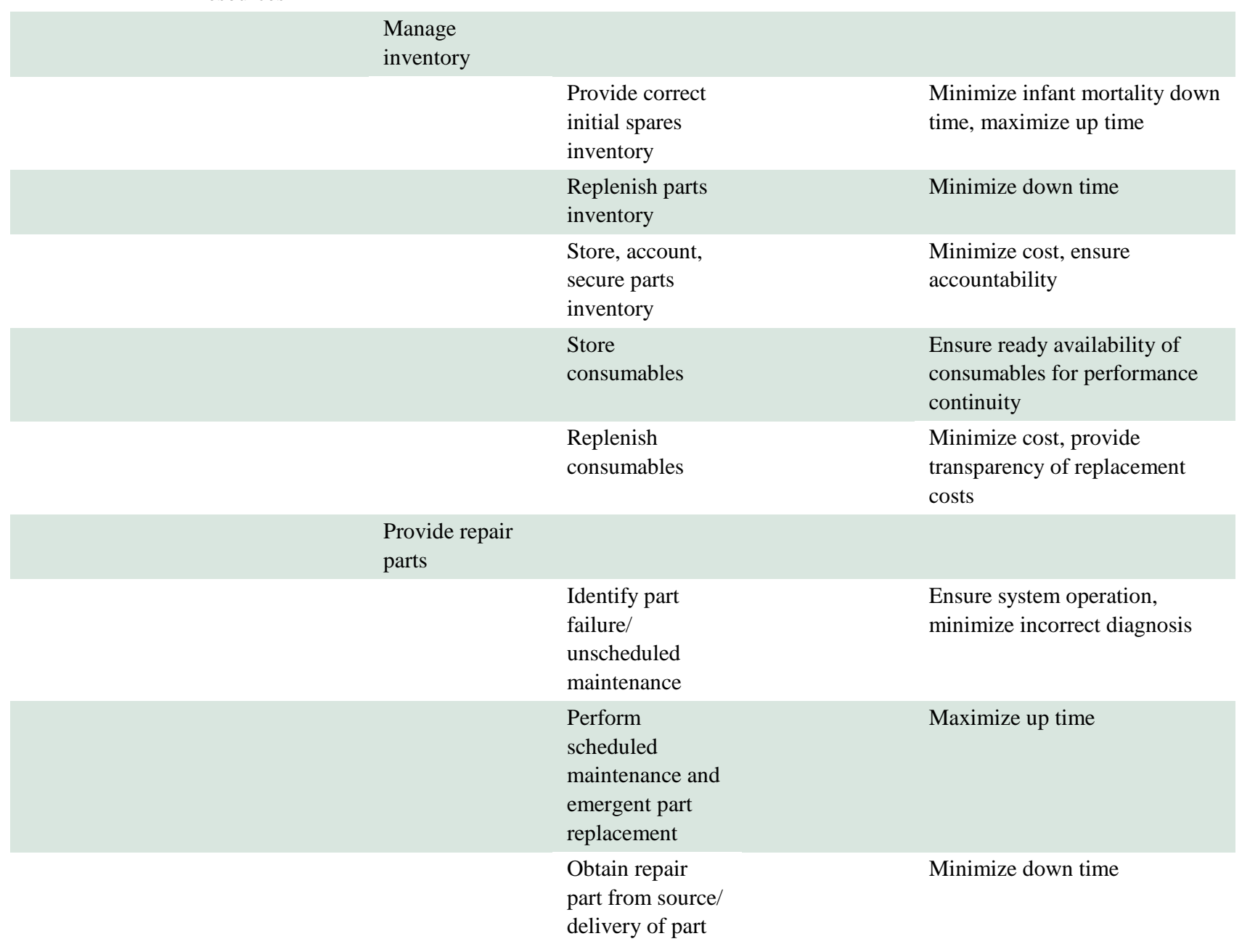




\begin{tabular}{|c|c|c|c|c|c|}
\hline \multirow[t]{9}{*}{ Level 1} & Level 2 & Level 3 & Level 4 & Level 5 & Goal \\
\hline & & & $\begin{array}{l}\text { Replenish parts } \\
\text { inventory }\end{array}$ & & $\begin{array}{l}\text { Provide necessary parts to } \\
\text { conduct anticipated } \\
\text { maintenance, minimize down } \\
\text { time }\end{array}$ \\
\hline & & $\begin{array}{l}\text { Provide } \\
\text { consumables }\end{array}$ & & & \\
\hline & & & $\begin{array}{l}\text { Use consumables } \\
\text { in scheduled } \\
\text { maintenance } \\
\text { activity }\end{array}$ & & $\begin{array}{l}\text { Maximize up time, maximize } \\
\text { system longevity }\end{array}$ \\
\hline & & & $\begin{array}{l}\text { Obtain initial } \\
\text { consumables }\end{array}$ & & $\begin{array}{l}\text { Provide for high performance at } \\
\text { start up }\end{array}$ \\
\hline & & $\begin{array}{l}\text { Manage } \\
\text { disposition }\end{array}$ & & & \\
\hline & & & Dispose of part & & $\begin{array}{l}\text { Remove dispositioned part } \\
\text { from inventory and program } \\
\text { control }\end{array}$ \\
\hline & & & $\begin{array}{l}\text { Evacuate part for } \\
\text { analysis }\end{array}$ & & $\begin{array}{l}\text { Conduct analysis to minimize } \\
\text { down time and improve overall } \\
\text { system performance }\end{array}$ \\
\hline & & & $\begin{array}{l}\text { Evacuate part for } \\
\text { repair }\end{array}$ & & $\begin{array}{l}\text { Minimize cost, ensure parts } \\
\text { accountability, minimize down } \\
\text { time }\end{array}$ \\
\hline
\end{tabular}

\subsubsection{Information Flows}

As described in Section 2.2, information is exchanged between stakeholders throughout SLD to manage the operational and analytic functions necessary to operate and maintain the program. The nature, frequency, and type of information exchanged are dependent on the site's phase in its lifecycle and the degree to which the site is engaged with the program. Operational information is managed through issue reports and monthly reports provided by the LMP to the sustainability manager or directly uploaded to Portal. Daily files are used to provide information on the status and performance of the radiation detection systems. This information has been used to provide portions of the Metrics Working Group results.

Dashed breaks in the connection lines in Figure 2.2 represent the interfaces and information transfer mechanisms by which information moves about the system. These information flows are subject to the technical capacity and participation of the source for transmitting the data contained within these pieces of information. 


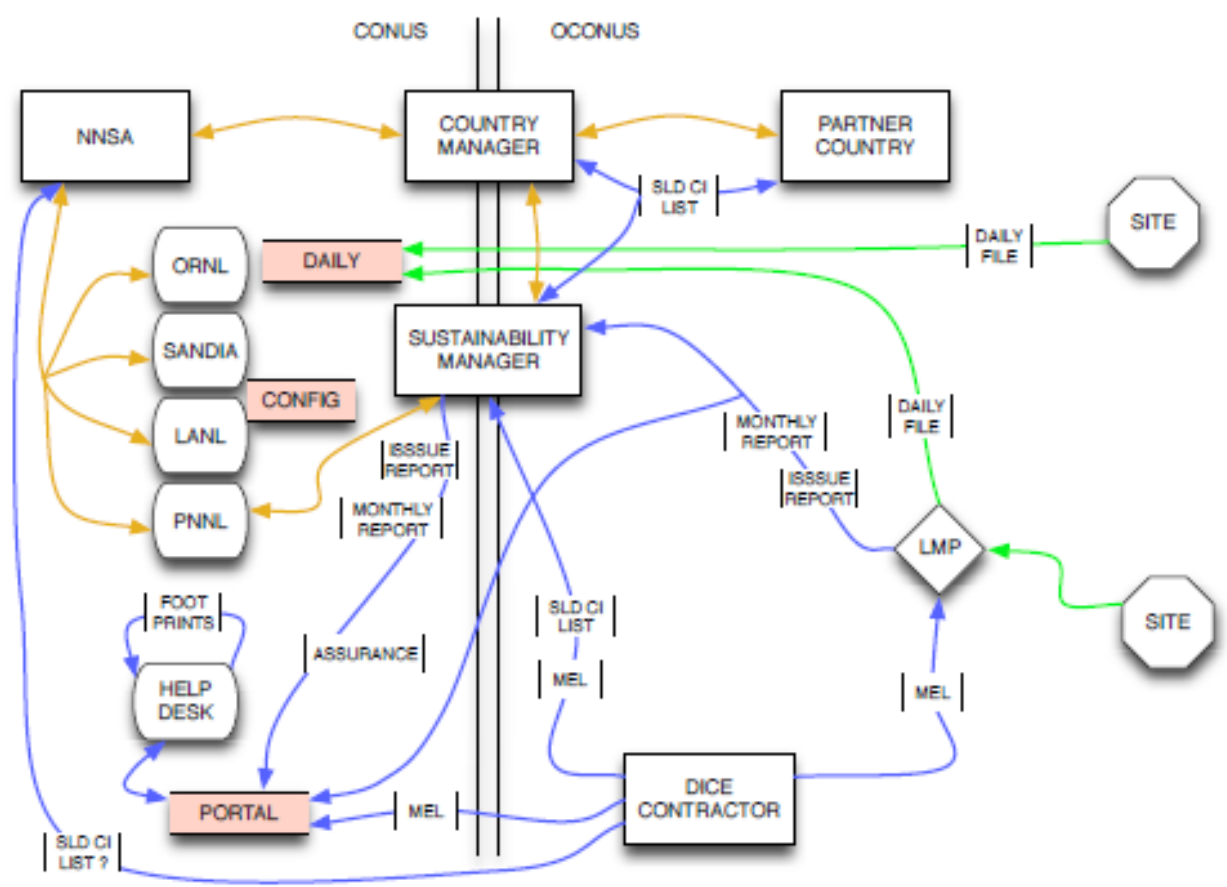

Figure 2.2. Information Flows in the SLD Sustainability Program

\subsubsection{Material Flows}

Material handling for SLD, briefly described in Section 2.2, is in place to ensure that equipment and spares are provided where and when needed by the site. The supply chain for these parts includes international manufacturing, storage, distribution, inventory, and delivery mechanisms. These connections cross a number of political, geographic, and technical boundaries that present constraints and obstacles for efficient and cost-effective delivery of spares to Core and Megaports sites. The dashed breaks on the connection lines in Figure 2.3 represent these potential boundaries that must be crossed to deliver a spare or other piece of equipment. In addition, a spares supply chain, including the sourcing, distribution, inventorying, and delivery of parts, must account for site needs, LMP capabilities, and partner country constraints to be effective post transition. Simultaneously, export controls for technology shipped beyond U.S. borders controls if and how these technologies can reach the foreign destination. 


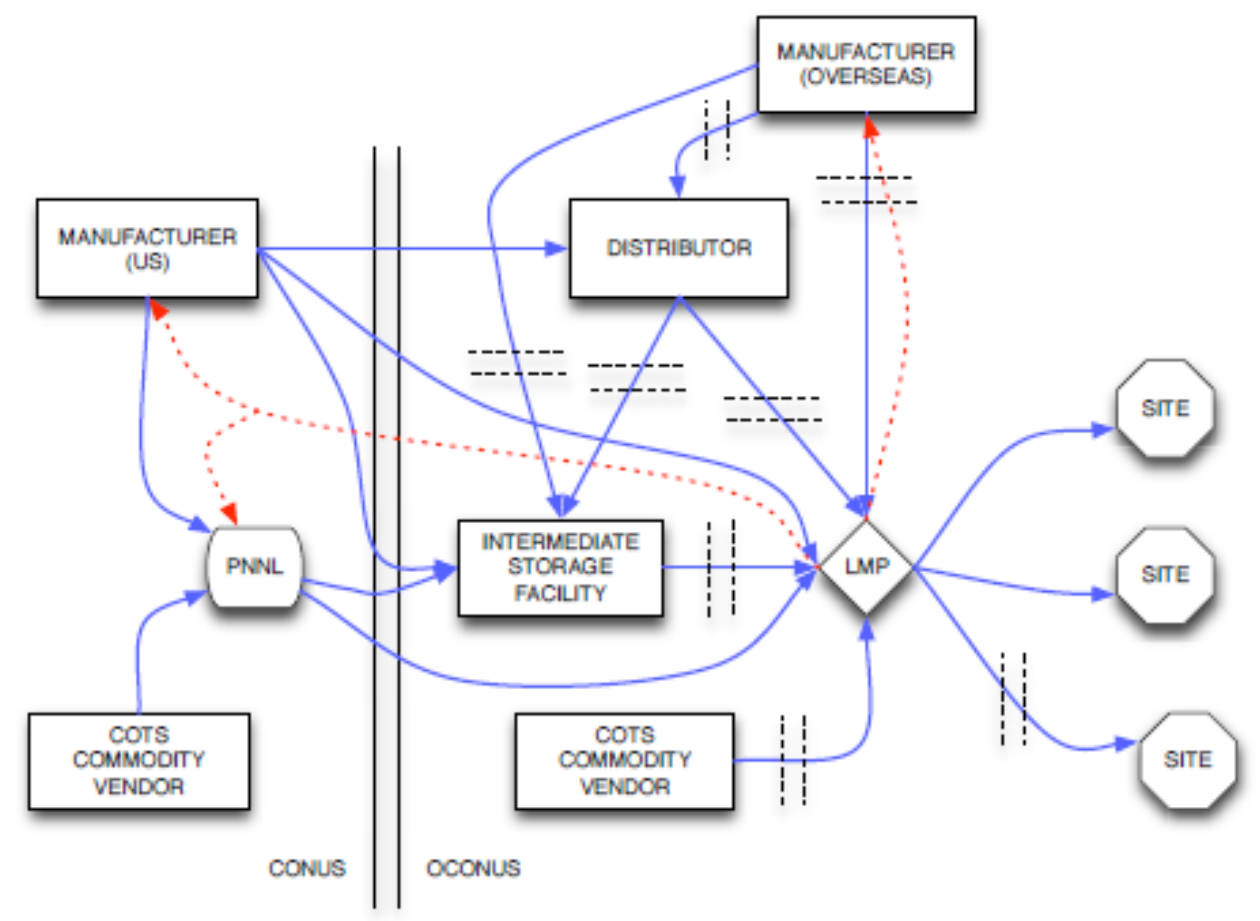

Figure 2.3. Material Flows in the SLD Sustainability Program

\subsection{Stakeholder Assessment}

\subsubsection{Stakeholders}

SLD stakeholders have unique goals, objectives, and positions within the hierarchy and operation of the program and contribute to the effective planning, design, implementation, operation, maintenance, and support of the detection systems. Developing a consensus for implementation of SLD practices and obtaining approval to operate these systems for the design life requires a prudent process of managing relationships, expectations, and requirements among these stakeholders. The following stakeholders are involved in SLD spares:

Country managers. DOE representatives that coordinate the process of implementing SLD in partner countries.

Partner countries. Administer the operation of and sustain SLD systems post transition. These sovereign entities ultimately take on the responsibility of managing the detection systems as part of an international radiation detection network.

Site. Have one or more SLD detection systems deployed on the premises or property and process traffic (cargo, vehicular, and pedestrian) entering the country.

Sustainability managers. Coordinate with country managers and oversee planning, design, and construction of SLD systems at partner country sites. Also coordinate training for operators, oversee operation during transition, and contract with LMPs for maintenance of the detection systems.

DICCE contractors. Design and construct the SLD detection systems at Megaports and Core sites for the initial phases. They have historically provided the set of initial spares for the site. 
Operators. Use and operate the SLD detection systems during transition and post-transition phases. Are typically an organizational or administrative entity of the partner country.

LMPs. Conduct maintenance on the SLD detection systems, manage spares inventories, and provide periodic maintenance reports to sustainability managers. LMPs identify indicators and warning signs of system failures, request spare parts, initiate replenishment of used inventory items, and perform necessary preventive and corrective maintenance on detection systems.

SLD Help Desk. Supports LMP monthly/periodic reporting, handles trouble calls by operators, and fields other issues that arise during transition of the site

\subsubsection{Stakeholder Interviews Summary}

Table 2.2 provides a list of stakeholders interviewed for this assessment. A detailed summary of all notes and feedback captured from these stakeholder interviews is provided in Appendix A.

Table 2.2. Interview Summary

\begin{tabular}{lll}
\hline \multicolumn{1}{c}{ Name } & \multicolumn{1}{c}{ Position } & \multicolumn{1}{c}{ Date } \\
\hline Eric Alderson & Sustainability Manager (Megaports) & February 22, 2012 \\
Paul Gray & Mobile Detection System Team (Core) & February 23, 2012 \\
Susan Para & Help Desk & February 23, 2012 \\
Kayla Swenson & Help Desk & February 23, 2012 \\
Rita Pool & Sustainability Manager (Megaports) & February 28, 2012 \\
Craig Nelson & Manager of Core Program & February 28, 2012 \\
Todd Bardin & Sustainability Manager (Megaports) & March 9, 2012 \\
John Dorian & SLD Spares Contract Technical Representative & March 14, 2012 \\
John David Mortensen & Megaports Project Manager & March 16, 2012 \\
\hline
\end{tabular}

The following is a high-level summary from the stakeholder interviews:

- Standards for spares management and information tracking: As will be seen as a recurring theme throughout this assessment report, there is a lack of standards related to the spares management process and management, accounting, and tracking systems. Often such management tools and methods are left to the sustainability manager's best judgment on how to manage their own spares process. Key take-aways that fall under this general heading include:

- There is no complete equipment/inventory list for every site and those inventory lists that do exist are not uniform.

- There are concerns over information sharing between stakeholders involved in the spare process, as well as between various employed information technology systems.

- Spare parts are often not ordered and replaced when they are used. This leads to a desire for potential automation in ordering spare replacement parts when they are consumed. Coupled with this notion is the idea of automatic notifications as to when spares that are time limited are approaching their expiration date. Given the lack of standardized spare part tracking systems, LMPs often develop their own unique tracking/database systems (i.e., Excel spreadsheet) for managing spares for their site. 
- Standards for maintenance repair: Some of the stakeholders reported that there were no standards on the approaches followed by LMPs when conducting repairs and maintenance troubleshooting and analysis. Key take-aways that fall under this heading include:

- Sometimes when conducting system repairs, spare parts are replaced until the reported problem is eventually resolved. This implies the potential for depleting spare parts when they are not really needed and extra cost to the program.

- $\quad$ On the analysis side, there are little in the way of long-term statistical/quality improvement processes and lifecycle assessments that might indicate the most faulty system components, failure causes, part mean time between failures, part mean time to repair, etc., which could be used to help increase overall system reliability, maximize system availability, and minimize program costs.

- Use of spare parts: A majority of spare parts in inventory at some sites have never been used. This outcome raises a concern on the shelf life of spare parts. That is, when some of these long-held spares are finally needed, their viability could be at risk. The take-away here is to consider the possibility of identifying spare part shelf life. Some parts may have indefinite shelf life and there would be no issues, but some may have shorter lives and should be tracked. In turn, it might be possible to stratify all SLD spare parts by shelf life and to provide automatic alerts to the LMPs when parts are nearing their expiration dates so they can be replaced beforehand.

- Value-added tax (VAT): Several stakeholders mentioned concerns about partner country customs processes and VAT on imports from the U.S. to Europe. Not only does VAT and custom processes imply additional costs, but associated time delays as well. As a result, sometimes sustainability managers may decide to have spare parts shipped to U.S. embassies within the partner countries and then delivered to the sites. This topic heading needs additional discussion for the development of potential concepts and recommendations to cope with these concerns.

- Desiccant: A recurring theme mentioned by several stakeholders centered on desiccant and this important consumable not being replaced often enough at some sites, which could result in system failures/damage from the presence of excess moisture. Additional take-aways under this heading include:

- Sometimes desiccant is not available at a site, which relates back to automated spare parts replenishment concepts. Alternatively, sometimes LMPs just forget to replace the desiccant after it has lost effectiveness.

- Some stakeholders also mentioned batteries as a frequently occurring problem both from the being consumable with limited shelf lives as well as unique sizes/uses so that they are not interchangeable.

\subsection{SLD Lifecycle}

Figure 2.4 shows the SLD site lifecycle. 


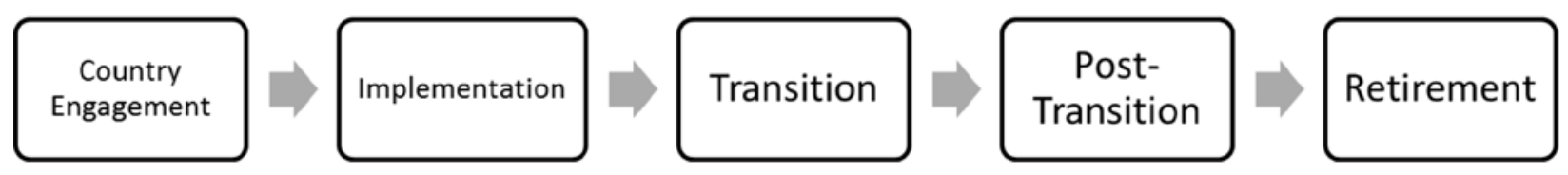

Figure 2.4. SLD Site Lifecycle

The stakeholders identified in Section 2.3 participate in specific capacities throughout the system lifecycle. The system lifecycle phases and events include:

- Country Engagement

- Implementation

- Acceptance Testing (Milestone)

- Transition

- Post-Transition

- Retirement

Figure 2.5 depicts a histogram of the number of Core and Megaports sites currently in each phase of the SLD site lifecycle.

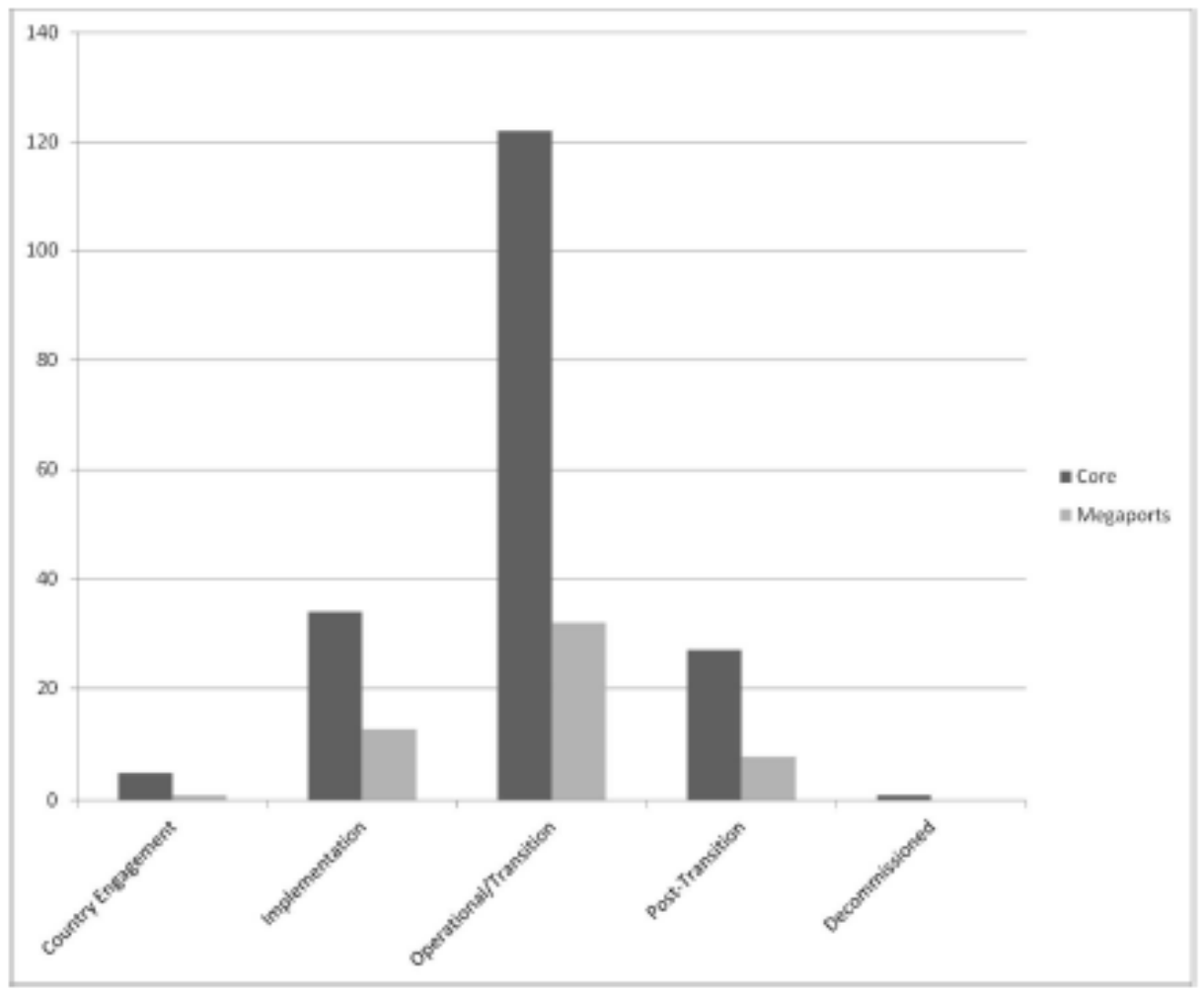

Figure 2.5. SLD Detection System Lifecycle: Site Histogram 


\subsubsection{Country Engagement}

During country engagement, DOE country managers initiate contact and negotiations with the partner country to secure buy-in and understand how SLD sites can be deployed at desired sites within the country.

\subsubsection{Implementation}

The design, contracting, and construction of sites is executed during the implementation phase. Once constructed and deployed, the systems are calibrated, made operational, and prepared for acceptance testing. The acceptance testing milestone serves as a hold point and allows sustainability managers and partner countries to test the operation of the system before implementation is deemed complete. Once the installation of the SLD system is accepted, the site can enter transition. Upon completion of acceptance testing, the site is provided an initial spares inventory to be maintained by the LMP.

\subsubsection{Transition}

Sites in transition are operated by the associated operator and maintenance is overseen by the sustainability managers and conducted by LMPs. Transition typically occurs over a three to five year period, during which time SLD provides the support mechanisms necessary to sustain the systems for the partner country.

\subsubsection{Post Transition}

Once transition is completed, sites are turned over to the partner country for full, or in some cases partial, operation and maintenance. The majority of the associated responsibilities reside with the partner country post transition, including sparing and LMP contracting. It is expected that partner countries will remain in post transition for the operational life of the detection system.

\subsubsection{Retirement}

Once SLD detection systems have met the full operational life or are no longer required, the systems must be retired and disposed. In many cases, where systems have been permanently placed, this may require excavation, dismantling, removing, and disposing of the systems. These additional activities add a cost burden to the partner country at the close of the system. It is not clear if SLD intends to re-engage the partner country at the time of retirement to replace aging systems with new technologies or if new technology deployments are the sole responsibility of the partner country.

Additionally, the retirement of certain consumables and spares (e.g., radioactive sources) must be planned for and accommodated. These typically occur on a regular basis and can be accomplished with existing approaches. It is important to note that not all partner countries have the same requirements for or methods of disposing of these items, and in some cases the cost may be significant.

\subsection{Spares Process}

The SLD spares process today uses several mechanisms to deliver parts to SLD sites. This is typically managed via input from LMPs to the sustainability managers, who coordinates parts procurement and delivery with other program personnel. LMPs provide parts needs in electronic format (e.g., Word or Excel documents), while some LMPs submit reports via the SLD Portal. 


\subsection{Spare Parts Data Sources}

In order to gain a complete picture of SLD spare parts data sources, a variety of avenues were explored. The primary source was the PNNL SLD Help Desk Portal. The Portal is still under development, but currently provides access to Help Desk service request information, PNNL equipment status, and some site profile information. Of the multiple information tabs available, the master equipment list, maintenance, and Help Desk were recommended as sources of parts information. The second source of spares information was the PNNL Purchasing and Expense System (PES). The PES provides most of the information found in the Help Desk tab of the Portal, but in a more consistent manner. Theoretically, a complete picture of the spares inventory at any SLD site can be reconstructed from three sources:

- Master equipment list found in the SLD Help Desk Portal

- Maintenance information found in the SLD Help Desk Portal

- PES (formerly known as Purchasing and Acquisitions or PACQ)

\subsection{Master Equipment List}

The master equipment list is a collection of DICCE final installation reports, which include both a site inventory and a spares inventory taken at the time of commissioning. The master equipment list is meant to capture deployed portal detection systems, allow performance analysis of deployed equipment, and support the property management process.

Approximately $80 \%$ of the sites are recorded in the list. Unless manually entered, sites transitioned after September 2011 are not in the master equipment list. Of the sites recorded, about 70\% have all of their RPMs recorded, while about 30\% may have a partial list (e.g., mobile RPMs may be included but not fixed RPMs).

Parts descriptions are not unique and are difficult to relate to the limited lists found in other data sources. Text parsing was applied to the descriptions with some success to determine strings of text in the description field that identify the same part (see Master Equipment List Entries by program mfgR1.xls). Site names have been normalized to those in the Los Alamos National Laboratory (LANL) RPM list so that the datasets may be joined. The LANL RPM data set also contains RPM manufacturer and SLD program name information that is important for subsetting data for investigation and summarization purposes. The contents of the master equipment list database are presented in Table B.1.

\subsection{Maintenance Information}

The maintenance database contains decrements to the spares inventory due to maintenance and repair. This information is extracted from LMP reports and represents approximately $90 \%$ of these types of removals from inventory. This data source describes the maintenance issue, diagnostic steps, and resolution of RPM problems requiring some maintenance activities. The parts used are embedded in a large (up to 2000 characters long) text field. Identification of the part would be a time-intensive manual process. Data are organized by where the issue is in the resolution process:

1. In progress

2. Uncertified complete 
3. Certified complete

The maintenance database contents are presented in Table B.2.

\subsection{Purchasing and Expense System}

The PES tracks additions to site spare parts inventories by recording parts ordered and paid through this PNNL system. P-card purchases are not recorded in this data system and may represent $10 \%$ of the total dollars spent on SLD spares. A description of the contents of the PES database is summarized in Table B.3.

Parts are listed under consistent names instead of being embedded in a lengthy text field.

\subsection{Observations}

One should be able to calculate current spares inventory by starting with the master equipment list, subtracting decrements found in the maintenance database, and adding increments found in the PES. However as stated above, the databases are not complete, thus the result of this simple calculation may be misleading. The accuracy of the calculation may be checked by comparing it to the LMP inventory records.

One challenge in maintaining current information in the databases is the way information is received by PNNL personnel. Final installation reports are received in a variety of formats, including .doc and .pdf formats. This inventory is manually extracted from to construct the master equipment list. In addition, other information is received as Excel files that cannot be imported directly, requiring additional manual data input. Manual input results in lags in data availability as well as data quality issues.

\subsection{Limited List of Parts for TSA and Aspect RPMs}

In order to assess the accuracy of derived inventories, it is important to have an all-inclusive list of (spare) parts for each RPM system: TSA and Aspect. The SLD SharePoint site provided baseline parts lists as well as country-specific lists. Additional information was received from Joan Young and John Dorian. The spare parts compilation tables for TSA and Aspect RPM systems are presented in Tables B.4 and B.5, respectively. 


\subsection{Preliminary Findings and Recommendations}

\subsection{Preliminary Findings}

Because of a range of organizational, historical, political, legal, and cultural factors, SLD currently operates under an extremely flat organizational hierarchy and these constraints will remain in place. Any effort to build a more sophisticated and robust spares system must account for these constraints.

Even though day-to-day operations and maintenance decision making must remain at the edge of the organization, the entire program would benefit immensely from a more standardized information management program. Such a program must provide tangible value to the operators, maintainers, and sustainability managers who routinely collect data about the status of sites, maintenance activities, and spares inventories.

The SLD Program has deployed 2,276 detection systems at 372 sites across 46 countries. The implementation of these systems has been managed through coordination between sustainability and country managers and partner country stakeholders, including foreign customs agencies, site operators and LMPs. Bringing these sites into a process that is centrally managed will enable a more streamlined, standardized spares process to take root and enable SLD to provide a global network of operational radiation detection systems at chokepoints throughout the international supply chain.

A successfully system must be able to accommodate the goals, objectives, and constraints of each lifecycle stage for which the spares program is in operation.

\subsection{Recommendations}

These recommendations will drive the spares study to successfully develop and deploy policy, guidelines, information products, and other components of a spares program to provide:

- better availability of detection systems through more timely maintenance action

- better visibility and accountability of spares inventory and requirements

- better mentoring and capacity growth among international partners and LMPs.

\subsubsection{Information Management}

SLD currently has information management practices in place to support the timely delivery of spares to sites in need of replacement parts. In the analysis phase, we will evaluate how this information is currently used, identify changes to data availability or exchanges that will aid in development of a more standardized set of operational data, and explore the potential to collect additional data for additional analysis to support efficient management of material and aid in development of a cost-effective, longterm, viable solution. These will be dependent on a number of variables, with anticipated key drivers of partner country involvement, availability of information, and the degree of work necessary to obtain the information relative to expected payoff.

Because so much operational authority and decision making has been pushed to the edge of the SLD organization, the information systems and periodic reporting procedures are, at present, a collection of independent and inconsistently applied solutions to particular problems identified over the course of many years in an evolving system. Consistent definitions, formats, repositories, and information management 
policies are prerequisites for a more efficient spares program. Moreover, the SLD Program as a whole would benefit from more effective information management across the entire Sustainability effort.

\subsubsection{Analysis Processes}

To ensure longevity of system operation post transition, it is critical that a thorough stakeholder analysis be conducted during the country engagement stage. This includes an assessment of partner country needs, requirements, and constraints (budget, technical competency, schedule), such as the ability to operate and maintain the system for the operational life. An LMP capable of performing the required maintenance is also critical to ensure longevity and performance of detection systems that leave direct SLD oversight.

To ensure longevity of system operation post transition, it is critical that a thorough stakeholder analysis be conducted for the LMP during the transition stage. This includes an assessment of site needs, requirements, and constraints, and the ability of the LMP to maintain the system for the operational life, follow reporting requirements, and adhere to other tasks required in the LMP statement of work. An LMP capable of performing the required maintenance is critical to ensure longevity and performance of systems that leave direct SLD oversight.

\subsubsection{Material Management}

There are only a few options available for physical handling of the spares, which fall broadly into two categories:

- SLD/LMP management of inventory,

- Manufacturer/distributor/third party management of inventory.

Hybrid approaches are also possible where different approaches are applied to different categories of SLD sites or different categories of parts.

\subsubsection{Issue Reporting}

Issue reports are provided by LMP for corrective maintenance and thus are provided post facto. In addition, reports are provided periodically and usually occur monthly or quarterly, with some reports issued semi-annually.

\subsubsection{Binning Strategies}

There are a number of ways in which pieces of the SLD Program and the Sustainability effort can be categorized, classified, and stratified. The art in the assessment approach will be to synthesize these binning strategies in a way that blends the program operations, stakeholder requirements, site needs, and support constraints in a manner that allows the program to successfully transition the sites to partner country operation so that the long-term viability and operation of these systems is supported. There are a number of alternative sparing strategies that can each address particular needs within the Sustainability Program. Some of these strategies are shown in Table 4.1.

\subsubsection{Maintenance Tasks}

Many maintenance tasks that are not necessarily included in an LMP statement of work explicitly require several project staff members and stakeholders to coordinate and approve (e.g., sustainability manager, Help Desk service request manager, LMP, contracts, technical administrator, and vendor)). The work being done on the statement of work template and getting LMPs to provide reports in a standardized 
format via the SLD Portal are steps toward a standardized, centrally managed process and a spares process will need to be linked to/integrated with.

Table 4.1. Potential Sparing Strategies

\begin{tabular}{|l|l|}
\hline \multicolumn{1}{|c|}{ Mechanism } & \multicolumn{1}{|c|}{ Strategy } \\
\hline \multirow{4}{*}{ Inventory and Storage } & Regional distribution warehouses \\
\cline { 2 - 3 } & Point-of-use (site) inventory \\
\cline { 2 - 2 } & LMP inventory \\
\cline { 2 - 2 } & Demand-driven supply (kanban) \\
\cline { 2 - 2 } & Hybrid approaches (rules of thumb, experience-based heuristics) \\
\hline \multirow{5}{*}{ Distribution } & Regional distribution warehouses \\
\cline { 2 - 2 } & Local sourcing \\
\cline { 2 - 2 } & Original equipment manufacturer/authorized vendor supply \\
\cline { 2 - 2 } & Hybrid approaches \\
\hline & Original equipment manufacturer \\
\cline { 2 - 2 } & Approved equivalent vendor/spare \\
\cline { 2 - 2 } & Authorized local source \\
\cline { 2 - 2 } & Authorized local manufacture \\
\hline
\end{tabular}





\subsection{References}

Hugos M. 2003. Essentials of Supply Chain Management. John Wiley and Sons, New Jersey.

Nymann D and J Levitt. 2001. Maintenance Planning, Scheduling, and Coordination. Industrial Press Inc., New York. 



\section{Appendix A - Stakeholder Interviews}

\section{A.1 Interview with Eric Alderson, 2/22/12}

- Eric has been working on Megaports since 2004, including training, project management, and sustainability; currently in sustainability management roll. He has worked in Israel.

- Two categories of spares: routine and catastrophic.

- Routine spare parts:

- A routine spare parts list is implemented

- To date, the spare parts list is relatively good, but we need to watch going overboard (listing too many spare parts)

- For Megaports, basic parts are TSA monitor, fixed-focus cameras, and lights.

- Catastrophic spare parts (i.e., external events):

- Lightning strike in Valencia, where they were able to repair the system within 10 days

- You could build into the system surge protection, but still a lightning strike is not expected.

- Sourcing spare parts:

- Much of the sourcing is from the U.S.; TSA is a large provider of spares, but they have been bought out by Rapidscan

- Uses four LMPs; looking for a vendor in Spain and asks them to get stuff in-country.

- Spectroscopic: if you have a detector go down you can still operate, but if you have a mox-switch that connects all the detectors go down, you have a problem.

- Graded approach to trouble shooting diagnostics and making repairs.

- LMPs do monthly maintenance reports; anything new is tracked through Help Desk.

- Takes a regular look at onsite inventory at least once a year.

- LMPs are required to have a spreadsheet of spare parts inventory.

- Does not wait until something is completely depleted to order.

- In Barcelona, Schneider Electric is vendor. They have a backup and can do a hot swap. For them he had to order two (one for the original part and a backup for the backup).

- For countries that might not be as technically competent they might designate an LMP for another country.

- Ninety percent of his spare parts have never been used.

- Catastrophic and routine spare parts:

- An example might be where you have two cameras. For the first, the lens might start to fog up, which is considered routine. For the second, a truck might drive by and knock over the pole it is mounted on, which would be catastrophic. 
- Asked if we are not going to be able to find much data because most decisions are made by rule of thumb, Eric agreed.

- Not looking at the next generation of RPMs any more. How to assure that we have the right supply of spare parts? Also, necessary spare parts may vary by region.

- Power problems in countries, including power conditions and power outages.

- In Barcelona recently, one of the systems appeared to be fine. Even though the fan was broken, the weather was mild enough that it did not need replacement.

- The ideal location for spare parts is the place that it will be used (in general).

- For Greece, Jordon, and Israel, spare parts are centrally located in Athens.

- In Greece, it took 9 months to get the VAT removed. Still trying to work this out because the U.S. government does not pay tax, especially when providing items. VAT is really high (I think he said about 22 or $23 \%$, maybe $42 \%$ ).

- Asked if the spares program is applicable between two points in time or applicable forever:

- If we help someone with spares in post transition, they are supposed to cover the costs

- $\quad$ The program is supposed to equip the country to do diagnostics themselves.

- Mentioned setting up a spares network, not just locations, but needs to include people too.

- Asked how many parts are on the list, answered more than 10 or 20, but not sure.

- Sustainability managers throughout the world should ask the LMPs to find vendors in their region that provide the spare parts required for that region.

- Asked if there are standards for Megaports on availability uptime (if a certain number of lanes fail would they just shut down the whole system)?

- Has not seen any guidelines, just makes a judgment call. For example, there was one case when 10 lanes were shut down, so they just focused on fixing one.

- Moving RPMs from a terminal in Barcelona to another terminal, but by moving two they would have effectively shut down four systems, which is not acceptable. Somewhere else he had two spare utility panels, so they exported those.

- A standardized spreadsheet would be really useful.

\section{A.2 Interview with Paul Gray, 2/23/12}

- Current role is mobile detection system team, leading PNNL effort for discrete monitoring (portals that don’t look like portals). Has done sustainability visits across Europe even though not a sustainability manager. Deals with Core.

- Mentioned that if the spares team is doing a lifecycle assessment of spares, a huge part of that is shipping.

- Depending on skill level of LMP, they start pulling out parts and replacing them until it works again, so there is not really any way of doing maintenance analysis. 
- Putting components in NEMA 3 cabinets for years and having a lot of problems because of moisture. Having to replace components monthly. Main problem is using the wrong parts, but their solution is just to buy more desiccant. Most of the problems inside the boxes are due to electrical component failures based on moisture.

- Get design documents now as attachments, so it is a lot more formal than it used to be. A lot of emphasis is on design/build. Problem is that the technical contracts are written by liberal arts majors who don’t really understand the technical aspects.

- For the last 7 years in Core there has been no formal design review.

- LMPs figure out which spares are needed to get component working to the point of acceptance and send the list of spares needed to someone else.

- Asked how we know what is in that one-year spare kit? Don't want to give them $200 \%$ and only use $20 \%$. Break out the spares included in spare kit based on shelf life. This will drive percentage you keep as spares.

- There are programmatic issues with the system:

- Model: PNNL provides support for 3 years and then the country takes over.

- 3 years is the projected time you would assume you could do your analysis for, but that is not what actually happens. A lot of countries don't transition after 3 years. Do we want to do the analysis assuming a 3-year period? Should we plan spares to allow for the transition after 3 years? Or plan to continue providing spares after 3 years?

- Asked if the Help Desk can arrange for spares to be shipped from other countries (drop ship from anywhere)? Thinks so; also mentioned Aspect may do their spares work individually.

- The push on the project is to procure locally.

- Time that the system is down must be taken into consideration, not just the cost of the spares.

- Help Desk people have a timeline that they are supposed to respond by.

- If populating 40 LMP storage sites for 5 years, there is an issue with lack of control. If you push it out to five people there is more opportunity for diagnostics.

- In calculating the cost, can figure out what goes into the SLD box and where that box is located.

- Part of the problem in the field is batteries. They bought a lot of equipment with regular rechargeable batteries. The problem is that people may think they can use that battery for unintended purposes and order more spares. There is a push to move to batteries that would be specific to the system (couldn't be used elsewhere).

- There are a lot of places you are surprised have a high speed CVN establishment.

- Any border where there are portals they will be facing both ways.

- The Core and Megaports people responsible for spares are the managers, called sustainability managers on the Core side and project managers on the Megaports side. 


\section{A.3 Interview with Susan and Kayla (Help Desk), 2/23/12}

- Kayla said she mostly works with getting things started rather than spares.

- Desiccant is huge; batteries have a lot of problems.

- There isn’t a help desk specifically for spares. The SLD help desk deals with everything.

- There is a classification of received calls for parts, logistics, and equipment. Sometimes calls in this category are spares.

- Everything is online, either through email or the Portal. They don't get calls, partially because everything they do is international, so there is a language barrier.

- They use the Footprints database (Numera Footprints).

- The types of people who should contact them (although they sometimes do get emails from other people too):

- LMP

- Sustainability managers

- Service request managers (PNNL staff/help desk staff who actually work the issues)

- Different levels of severity:

- Critical: The whole site is down.

- Major: Something is not working.

- Minor: Batteries, parts; the site is still operational.

- Sometimes Susan directly orders items, but usually she writes the item numbers down and gives them to someone else.

- They used to buy items in bulk (i.e. desiccant), but the problem was it would all be in one bag and then when you opened the bag it would start sucking up the moisture. Now, they have started individually sealing the desiccant.

- Batteries have a life span of about 3 years. Having a system in place where you know when it should expire would help to avoid all the back end rushing. Right now they just wait until they are completely dead and then there is no quick way to make the delivery. Susan referred to one case in which someone ran out completely of ink for their printer, but didn't order more until it was completely gone, and it took months to get more to them.

- To send stuff to Mexico, they have to get a donation letter from the government for everything (even something as little as desiccant).

- They just had a shipment of parts sent back because the receiver claimed they didn’t work.

- Equipment Logistics Center is another resource for shipping parts to consider.

- Sometimes there will be confusion because a sustainability manager is set up by country, and then they don’t know about the help desk. 
- There seems to be a lack of communication. Some people don't know who to contact or don't even know the help desk exists.

- People aren’t required to use the help desk to make contracts, which causes problems with collecting data.

\section{A.4 Interview with Rita Pool and Craig Nelson, 2/28/12}

- Rita is the Megaports sustainability manager for Taiwan and Korea. Taiwan has 40 RPM, Korea has four RPMs, but each has just one port.

- She knows how many parts she started with and would love to see where the Portal has all this information. She would like it to be laid out with each part number and when it was used and replaced and data about which company used it, etc.

- When the help desk recommends a new part it should set off an automatic trigger to reorder.

- Footprints: you can see the email chains coming through the help desk. The problem with footprints is that not everybody can look at it. She can't look at it as a sustainability manager even as read-only. It would be really useful to her because she could look back and see when someone asked for a part and how long it should be.

- The problem is no follow up from the help desk once they assign a subject matter expert. Once, they ended up with six help desk tickets for the same thing because it was never followed up with. Also, they used to charge by number of tickets.

- For desiccant they used to use packets, date the packets when they put it them in, and use that to know when to change it. They used to have LMPs that would just put the current date on the desiccant when the sustainability managers were coming around because they couldn't tell that it was actually soaking up moisture. Now they have a container sort of system where they take the top off, pour the water off, and refill the desiccant, so it's easier for them to tell that the desiccant is actually doing something.

- She thinks contracts should be allowed to go into the Portal to change LMP information since they know it first.

- When it comes to shipping spares, each country has their own little isms of how it needs to be done. People always email her to get LMP contact information even though it's on the website because they think it's changed (even though she's been in charge the whole time).

- Craig manages Core. There are 23 countries that he deals with. With Core especially there is uniqueness in getting stuff into each country: who to contract, who to ship to (ship to embassy who forwards to LMP, or ship straight to LMP).

- They have a great embassy in Slovakia, should they become a European hub for spares?

- There are some LMPs who have enough spares already (Bulgaria in particular).

- Rita said they do a yearly inventory.

- The major difference between Core and Megaports is for Megaports you typically don't have sites scattered throughout the country, Core sites are scattered throughout the country. 
- Another side to consider is in determining which spares are most important. One part he mentioned requires two spares for every 10, but really only need to be replaced very rarely. How do you know if the spares are still good by the time they're needed?

- Joan Young has looked at what the important spares are. Mean time for failure is one thing to look at, but also mission critical. Also, what parts should be kept on site and what should just be ordered when it runs out?

- Typically RPMs shouldn't have shelf life.

- Craig said their biggest problem is software.

- Systems get old. How frequently do we refresh technology?

- Rita said the top issue affecting the spares process is making sure the spares are replaced when they are used. If they could get automatic replacement/reorder that would be nice.

- It was suggested to look at the picture as a whole and find common ground between all of them before focusing on one country in particular, so we know which things can be generalized.

- Singapore is a pretty good country to consider when it comes to dealing with government issues.

- The problem with Spain and Singapore is they don't have Core. Jordan was the only country that Craig could think of with both Core and Megaports sites. He said realistically we'll probably have to pick two different countries to study.

- To find a country with a Core site, he suggested Azerbaijan (sustainability manager is Mark Dillner), Mongolia (has a good LMP, Virginia Harter is the sustainability manager), and Lithuania and Croatia, (Dave Smith is sustainability manager). All of these are Core sustainability managers and each has multiple countries they deal with, usually one that is an active country and one that is kind of idle, and one that is in between.

- Rita thought Taiwan would be better to look at than Korea for Megaports.

- Shain Pepper is sustainability manager for Singapore and Eric Alderson has Europe.

- LMP is under contract to respond within 24 hours. If they can't have it up within 48 hours they have to call the sustainability manager.

- There are two ways an LMP works. A typical LMP contract says they have to do routine and nonroutine maintenance. They are trying to get customs to do more of the routine maintenance (paint, replace desiccant). If the LMP goes out to fix one thing and sees another problem, they need to fix it and fill out a report. If there is something that the LMP can't solve on their own and has to reach back to the help desk, then they open a service request. Occasionally calling the service desk may just be to get more spare parts. Emergency maintenance is the same thing, where if they fix it they must file an issue report. If it goes to the help desk they open a service request.

\section{A.5 Interview with Todd Bardin, 3/9/12}

- Deals with Megaports in Mexico, Honduras, Jamaica, and the Bahamas. He noted that Core no longer exists in Mexico. 
- Had the so-called best practice. If people were to follow sorting, standardizing, the five things that he talked about, it would go a long way.

- Spares come in and people assume that the parts are all there and that the LMP will know, but sometimes they don't.

- The problem with sending equipment to other countries is the customs clearance process, even though we have arrangements with the other countries to not tax our stuff.

- Easier to get items into Mexico from other countries than from the U.S.

- Mentions one attribute that makes a specific location more attractive is the ease of customs clearance. Right now they have two handhelds delayed in Jamaica because of tax waiver issues. Not an issue with our paperwork but with their customs. Nothing we can do but wait.

- It would be good if we could get some sort of regional risk map about customs.

- Equipment Logistics Center. He recommended talking to Jack Small.

- Started to say that an LMP isn't really necessary in every country, but you do need an IT maintenance person nearby because that is where most of the problems arise. LMPs sometimes have IT capabilities, sometimes not. We should have better requirements on what skills and background an LMP should have. Should hire people with IT expertise and train them in RPMs because they don't have as much expertise in IT.

- RPMs are very hearty because they are simple. There are no moving parts.

- The government should define the requirements. Should include scalable, moveable, etc. We haven't defined a set of requirements so it's left up to the country and they tend to overdesign.

- Contact Keith Middleton if we're interested in talking about how RPMs might be redesigned more simply.

- Spares have to be driven by the sustainability manager, where they would do an inventory on every visit, making sure the LMP is keeping track of things.

- Suggestions for managing spares:

- Are they sorted?

- Are they standardized?

- Are they kept clean and in an orderly fashion?

- Do you have an up to date inventory?

- Goes to each country roughly quarterly (he said more frequently of late because of some transition they're doing).

- Help desk is doing a good job, but this program has been around for a really long time and they don't have all the data. Might have to base the spares analysis on information other than historical data.

- Michael Fox (Honduras) is a really great LMP to work with, very honest. Honduras is one of the biggest (maybe the biggest) ports in Central America. 


\section{A.6 Interview with John David Mortensen, 3/16/12}

- Megaports project manager.

- Involved for over 7 years and is currently a Megaports project manager. Megaports itself was less than a year old when he joined. He started at headquarters and has been a project manager for about 4 years.

- Up until about 18-24 months ago they considered spares the project manager's responsibility. Then it became the sustainability manager's responsibility.

- A project manager could focus on implementation and didn't have to worry about spares, sustainability, LMP.

- There are still project and sustainability managers, but now at the acceptance phase the project manager hands off responsibility.

- Question of who is responsibility for spares. Would be helpful for it to be crystal clear who provides the spares and what they are.

- There is a certain set of TSA spares, good for 1 to 10 RPMs. Which spares are critical for the TSA initial suite of spares needs to be determined.

- Spares for RPMs are kind of a black box. Sustainability managers don't really know what they need.

- A specific sustainability manager might have enough background to think of asking Schneider.

- The sustainability manager is the center of universe. They are the connection between everyone at PNNL, HQ, etc., and the partner country. We need to have reasonable expectations. They can't do everything.

- Should set up consulting systems, some sort of support service so there's a trigger when the sustainability manager needs to start thinking about spares. That way they don't always have to be thinking about it.

- Two operating extremes: sustainability managers call when they need spares or they get 5 years of spares. We need to figure out where between these two extremes we should fall. It might be different for different countries.

- There are periods throughout the lifecycle that are related to the spares process. From the beginning, when the sustainability manager is in the country, maybe there are a few things that you as a service provider would like to know. There might be something the service provider could tell the sustainability manager that would help in determining what's needed for the system.

- Training, spares, maintenance (LMPs), help desk are all related to the spares process. Asking the sustainability manager to do more than they should do, so they don't have time to focus on the things they really need to focus on.

- For spares you should be able to sit down and answer a set of questions, and then the system could decide what your spares program should be. There should be one person who oversees the bigger picture (the Tsar), who would be able to give a recommendation. They would also need to balance how much was determined by the tsar vs. the system. 
- There are other people who work in these countries. Are we leveraging within PNNL, what have you learned about shipping stuff into Croatia?

- Eventually the sustainability manager will not be there. What relationship should we have, training services with the partner country, to deal with this? 



\section{Appendix B - System Datasets and Parts Listings}

\section{B.1 SLD Spares Datasets Contents}

Table B.1. Master Equipment List

\begin{tabular}{|c|c|c|c|c|c|}
\hline Name & Type & Length & Format & Informat & Description \\
\hline Category & 2 & 40 & $\$$ & $\$$ & $\begin{array}{l}\text { Part/equipment category e.g., CAS, N/C, } \\
\text { OPS, OCR, etc. }\end{array}$ \\
\hline Comments & 2 & 250 & $\$$ & $\$$ & Comment field \\
\hline Country & 2 & 20 & $\$$ & $\$$ & Country name \\
\hline Date Installed & 2 & 10 & $\$$ & $\$$ & Date (part/equipment?) installed \\
\hline Description & 2 & 165 & $\$$ & $\$$ & Part/equipment description \\
\hline ECCN & 2 & 65 & $\$$ & $\$$ & $?$ \\
\hline $\begin{array}{l}\text { Installed By } \\
\text { Procured By }\end{array}$ & 2 & 25 & $\$$ & $\$$ & $\begin{array}{l}\text { Company that installed/procured part/ } \\
\text { equipment }\end{array}$ \\
\hline Location & 2 & 45 & $\$$ & $\$$ & Part/equipment location at site \\
\hline Manufacturer & 2 & 60 & $\$$ & $\$$ & Part/equipment manufacturer \\
\hline Model & 2 & 190 & $\$$ & $\$$ & Part/equipment model \\
\hline $\mathrm{PO}$ & 2 & 10 & $\$$ & $\$$ & Purchase order number? \\
\hline Quantity & 2 & 25 & $\$$ & $\$$ & Quantity \\
\hline Received Date & 2 & 10 & $\$$ & $\$$ & Date part/equipment received \\
\hline Reference & 2 & 75 & $\$$ & $\$$ & $?$ \\
\hline Retired Date & 2 & 5 & $\$$ & $\$$ & Date part/equipment retired \\
\hline RowID & 1 & 8 & BEST & BEST & Unique ID \\
\hline Schedule B & 2 & 20 & $\$$ & $\$$ & $?$ \\
\hline Serial Number & 2 & 120 & $\$$ & $\$$ & Serial number of part/equipment \\
\hline Site & 2 & 40 & $\$$ & $\$$ & Site name \\
\hline Subcategory & 2 & 60 & $\$$ & $\$$ & $\begin{array}{l}\text { Part/equipment subcategory e.g., CAS-Server, } \\
\text { N/C-LAN cabling, OPS-Parts, OCR-Server }\end{array}$ \\
\hline Supplier Vendor & 2 & 40 & $\$$ & $\$$ & Supplier/vendor of part/equipment \\
\hline $\begin{array}{l}\text { Supplier Vendor } \\
\text { Part }\end{array}$ & 2 & 35 & $\$$ & $\$$ & Part supplied or vended \\
\hline Value & 2 & 25 & $\$$ & $\$$ & (Total?) value of part(s)/equipment \\
\hline WBS & 2 & 15 & $\$$ & $\$$ & Work breakdown structure number \\
\hline Warranty & 2 & 10 & $\$$ & $\$$ & Warranty information \\
\hline Site & 2 & 50 & & & $\begin{array}{l}\text { Site compatible with SiteName in other } \\
\text { related datasets (PNNL generated) }\end{array}$ \\
\hline MFG & 2 & 10 & $\$$ & $\$$ & $\begin{array}{l}\text { RPM manufacturer (Aspect or TSA) (PNNL } \\
\text { generated from join to LANL RPM list after } \\
\text { site name cleanup) }\end{array}$ \\
\hline ProgName & 2 & 15 & $\$$ & $\$$ & $\begin{array}{l}\text { Program name (Core, FCS Russia, } \\
\text { Maintenance or Megaports) (PNNL generated } \\
\text { from join to LANL RPM list after site name } \\
\text { cleanup) }\end{array}$ \\
\hline
\end{tabular}


Table B.2. Maintenance Certified

\begin{tabular}{|c|c|c|c|c|c|}
\hline Name & Type & Length & Format & Informat & Description \\
\hline Contract & 2 & 30 & $\$$ & $\$$ & Maintenance contract number \\
\hline Country & 2 & 20 & $\$$ & $\$$ & Country name \\
\hline Date Issue Reported & 1 & 8 & MMDDYY & MMDDYY & Date issue reported \\
\hline Date Resolved & 1 & 8 & MMDDYY & MMDDYY & Date issue resolved \\
\hline Date of Response & 1 & 8 & MMDDYY & MMDDYY & Date issue reported was responded to \\
\hline Diagnostic Steps & 2 & 2500 & $\$$ & $\$$ & Description of the diagnosis steps \\
\hline Email & 2 & 35 & $\$$ & $\$$ & Maintenance contractor email? \\
\hline Equipment Lane & 2 & 110 & $\$$ & $\$$ & $\begin{array}{l}\text { Description of where problem } \\
\text { equipment is located at the site }\end{array}$ \\
\hline $\begin{array}{l}\text { Help Desk } \\
\text { Assistance Required }\end{array}$ & 2 & 5 & $\$$ & $\$$ & Yes/No \\
\hline Help Desk Involved & 2 & 5 & $\$$ & $\$$ & Yes/No \\
\hline $\begin{array}{l}\text { Help Desk Service } \\
\text { Request }\end{array}$ & 1 & 8 & BEST & BEST & Yes/No \\
\hline Issue Description & 2 & 1000 & $\$$ & $\$$ & Description of the issue \\
\hline Issue Category & 2 & 40 & $\$$ & $\$$ & $\begin{array}{l}\text { Part/equipment high-level category } \\
\text { e.g., radiation detection, CAS, } \\
\text { operations }\end{array}$ \\
\hline Issue Subcategory 1 & 2 & 50 & $\$$ & $\$$ & $\begin{array}{l}\text { Part/equipment lower level category } \\
\text { e.g., SPM, CAS workstation, } \\
\text { operations power }\end{array}$ \\
\hline Issue Subcategory 2 & 2 & 50 & $\$$ & $\$$ & $\begin{array}{l}\text { Part/equipment next lower level } \\
\text { category e.g., SPM, CAS workstation } \\
\text { hardware, operations power generator }\end{array}$ \\
\hline Issue Subcategory 3 & 2 & 50 & $\$$ & $\$$ & $\begin{array}{l}\text { Part/equipment next lower level } \\
\text { category }\end{array}$ \\
\hline Issue Subcategory 4 & 2 & 50 & $\$$ & $\$$ & $\begin{array}{l}\text { Part/equipment next lower level } \\
\text { category }\end{array}$ \\
\hline Other Parts Used & 1 & 8 & BEST & BEST & $\begin{array}{l}\text { Number of parts used other than the } \\
\text { part with the original issue }\end{array}$ \\
\hline Phone Number & 2 & 20 & $\$$ & $\$$ & Maintenance contractor phone number \\
\hline Resolution & 2 & 2000 & $\$$ & $\$$ & $\begin{array}{l}\text { Description of how the issue was } \\
\text { resolved }\end{array}$ \\
\hline Site & 2 & 35 & $\$$ & $\$$ & Site name \\
\hline Spare Parts Used & 1 & 8 & BEST & BEST & Number of spare parts used \\
\hline Title & 2 & 65 & $\$$ & $\$$ & ? \\
\hline Unique ID & 1 & 8 & BEST & BEST & Unique ID \\
\hline Work Completed By & 2 & 300 & $\$$ & $\$$ & Person who completed maintenance \\
\hline Site & 2 & 50 & & & $\begin{array}{l}\text { Site compatible with SiteName in } \\
\text { other related datasets (PNNL } \\
\text { generated) }\end{array}$ \\
\hline MFG & 2 & 10 & $\$$ & $\$$ & $\begin{array}{l}\text { RPM manufacturer (Aspect or TSA) } \\
\text { (PNNL generated from join to LANL } \\
\text { RPM list after site name cleanup) }\end{array}$ \\
\hline ProgName & 2 & 15 & $\$$ & $\$$ & $\begin{array}{l}\text { Program name (Core, FCS Russia, } \\
\text { Maintenance or Megaports) (PNNL } \\
\text { generated from join to LANL RPM } \\
\text { list after site name cleanup) }\end{array}$ \\
\hline
\end{tabular}


Table B.3. Purchasing and Expense System

\begin{tabular}{|l|l|l|l|l|l|}
\hline \multicolumn{1}{|c|}{ Name } & Type & Length & Format & Informat & \multicolumn{1}{c|}{ Description } \\
\hline $\begin{array}{l}\text { BUYER PREFERRED NAME } \\
\text { FM }\end{array}$ & 2 & 25 & $\$$ & $\$$ & Buyer name \\
\hline CC TITLE & 2 & 65 & $\$$ & $\$$ & Cost code title \\
\hline CHARGE CD & 2 & 10 & $\$$ & $\$$ & Charge code \\
\hline COST CLASS & 2 & 20 & $\$$ & $\$$ & Cost class \\
\hline COST CLASS TITLE & 2 & 30 & $\$$ & $\$$ & Cost class title \\
\hline COST FAM & 2 & 250 & $\$$ & $\$$ & Cost family \\
\hline COST FAM TITLE & 2 & 70 & $\$$ & $\$$ & Cost family title \\
\hline PHYSICAL NATURE CD & 2 & 5 & $\$$ & $\$$ & Physical nature code: ' , G or S \\
\hline PO LINE DESC & 2 & 300 & $\$$ & $\$$ & Purchase order line description \\
\hline PO LINE NO & 2 & 5 & $\$$ & $\$$ & Purchase order line number \\
\hline PO NO & 2 & 10 & $\$$ & $\$$ & Purchase order number \\
\hline RCVR SA TITLE & 2 & 50 & $\$$ & $\$$ & Receiver subaccount title \\
\hline RCVR SUBACCT & 1 & 8 & BEST & BEST & Receiver subaccount \\
\hline RPT DATE & 2 & 35 & $\$$ & $\$$ & Report date \\
\hline TD PO AMT & 2 & 15 & $\$$ & $\$$ & $?$ \\
\hline TECH ADMIN PREFERRED & 2 & 30 & $\$$ & $\$$ & Technical administrator name \\
NAME FM & & & & & \\
\hline TOE & 2 & 20 & $\$$ & $\$$ & $?$ \\
\hline TOE TITLE & 2 & 35 & $\$$ & $\$$ & $?$ \\
\hline TRANS AMT & 2 & 35 & $\$$ & $\$$ & Transaction amount \\
\hline TRANS BRDN AMT & 1 & 8 & BEST & BEST & Transaction burdened amount \\
\hline VENDOR NAME1 & 2 & 45 & $\$$ & $\$$ & Vendor name \\
\hline WBS & 2 & 15 & $\$$ & $\$$ & Work breakdown structure \\
\hline WBS TITLE & 2 & 45 & $\$$ & $\$$ & Work breakdown structure title \\
\hline X & 2 & 15 & $\$$ & $\$$ & $?$ \\
\hline X 1 & & & & & ? \\
\hline
\end{tabular}

\section{B.2 SLD System and Spare Parts Listings}

Table B.4 presents the spare parts and subparts discovered by searching available data sources. A base list was found on the SLD SharePoint site and the information is presented in the first three columns. The first column contains the TSA part number for major parts; the second column shows subparts of the major part along with the associated TSA subpart number and/or a part description. Any additional information about the (sub)parts is found in the third column. Four other data sources provided information on parts that may be interchangeable with parts in the base list. This information is listed in columns four to seven. 
Table B.4. TSA Parts List

TSA PowerPoint Document dated 01/12/2012

\begin{tabular}{|c|c|c|c|}
\hline TSA Part \# & Description & Comment & Recommendation \\
\hline 0095 & DESICCANT \#6 & & TM-850 (1) \\
\hline 0301E & CABLE (CAT 5, 4 FOOT) & & \\
\hline 0344D & CABLE (3 CON 18G 76”) & & \\
\hline 0350 & CABLE (COAX LOT) & & O353: TM-850 COAX LOT \\
\hline 0418 & AC LINE FILTER & & \\
\hline $2533 C$ & TERMINAL BLOCK 3 (10 POS.) & & \\
\hline $2533 \mathrm{E}$ & AC TERMINAL BLOCK & & \\
\hline $2533 \mathrm{~F}$ & $\begin{array}{l}\text { AC TERMINAL BLOCK W/5 } \\
\text { AMP SWITCH AND SERVICE } \\
\text { OUTLET }\end{array}$ & & \\
\hline 2802B & CAT5 X-OVER CABLE 7 FT & & \\
\hline 3450 & DETECTOR BRACKETS & & \\
\hline $3450 \mathrm{C}$ & LARGE TYWRAPS & & \\
\hline 3470 & PIPE CLAMPS FOR He3 TUBES & & \\
\hline 4804 & 6X31” LEAD SHIELDS & & \\
\hline 4875 & $\begin{array}{l}\text { LARGE POLY BLOCKS ( } 2 \\
\text { HOLE) }\end{array}$ & & \\
\hline 6456A & 12V 18 AH BATTERY & & $\begin{array}{l}\text { \#6456B: BATTERY 12v } 26 \\
\text { AMP. HOUR }\end{array}$ \\
\hline 6666D3 & $\begin{array}{l}\text { ULTRASONIC OCCUPANCY } \\
\text { SENSOR }\end{array}$ & & \\
\hline $6720 \mathrm{C}$ & He3 TUBE (2” X 36”) & & \\
\hline 6987 & MASTER ENCLOSURE & & \\
\hline 6987A & SLAVE ENCLOSURE & & \\
\hline 7230 & $\begin{array}{l}\text { HEATER STRIP WITH } \\
\text { THERMOSTAT }\end{array}$ & & \\
\hline 7346 & RED STROBE $12 \mathrm{~V}$ & & \\
\hline 7346A & BLUE STROBE $12 \mathrm{~V}$ & & \\
\hline $7346 \mathrm{C}$ & SPEAKER / SIREN (ELK-1RT) & & \\
\hline 7354 & AMBER FAULT LIGHT & & \\
\hline 7818 & MAGNETIC TAMPER & & \\
\hline $8200 \mathrm{~A}$ & DA630 (GAMMA DETECTOR) & $\begin{array}{l}\text { INCLUDES TSA \# } \\
\text { 8870AP (VD-580) x } 1\end{array}$ & $\begin{array}{l}\text { \#8244: DA1248 (GAMMA } \\
\text { DET.) }\end{array}$ \\
\hline \multicolumn{4}{|c|}{8774 MASTER CONTROL PLATE INCLUDES: } \\
\hline & 0360 (MASTER CABLE LOT) & & \\
\hline & $\begin{array}{l}2532 \text { (25 PIN TERMINAL } \\
\text { BLOCK, TBX) }\end{array}$ & & \\
\hline & $\begin{array}{l}\text { 2533B (TERMINAL BLOCK } 2 \\
(20 \text { POSITION)) }\end{array}$ & & \\
\hline & $\begin{array}{l}\text { 2533C (TERMINAL BLOCK } 3 \\
(10 \text { POSITION)) }\end{array}$ & & \\
\hline
\end{tabular}




\begin{tabular}{|c|c|c|c|}
\hline TSA Part \# & Description & Comment & Recommendation \\
\hline & $\begin{array}{l}\text { 3204C (MACHINED MASTER } \\
\text { ALUM. PLATE) }\end{array}$ & & \\
\hline & $\begin{array}{l}\text { 7346B (SIREN DRIVER, ELK- } \\
100)\end{array}$ & & \\
\hline & 8699P (PMFX4 BOX ASSY.) & & $\begin{array}{l}\text { \#8699: PMFX4 } \\
\text { (COMPLETE) }\end{array}$ \\
\hline & 9411 (SC-770 CONTROLLER) & $\begin{array}{l}\text { INCLUDES TSA \# } \\
\text { 8751AA x } 1 \text { (SC-771 } \\
\text { BOARD) }\end{array}$ & $\begin{array}{l}\text { \#9411: SC-770 \#8753: SC- } \\
771 \text { BOARD }\end{array}$ \\
\hline & $\begin{array}{l}9413 \text { (SCA-775 } \\
\text { SUBASSEMBLY) }\end{array}$ & $\begin{array}{l}\text { INCLUDES TSA \# } 8754 \\
\text { x } 1 \text { (SC-774 BOARD) } \\
\text { AND TSA \#8403AP x } 2 \\
\text { (HHV BOARD) }\end{array}$ & $\begin{array}{l}\text { \#9413: SCA-775 \#8754: } \\
\text { SCA-774 BOARD \#8403A: } \\
\text { HHV-448D }\end{array}$ \\
\hline \multicolumn{4}{|c|}{ 8774A SLAVE CONTROL PLATE INCLUDES: } \\
\hline & 0360A (SLAVE CABLE LOT) & & \\
\hline & $\begin{array}{l}2532 \text { (25 PIN TERMINAL } \\
\text { BLOCK, TBX) }\end{array}$ & & \\
\hline & $\begin{array}{l}\text { 2533D (TERMINAL BLOCK } 5 \\
\text { (10 POS.W/ GND)) }\end{array}$ & & \\
\hline & $\begin{array}{l}\text { 3204B (MACHINED SLAVE } \\
\text { ALUM. PLATE) }\end{array}$ & & \\
\hline & 8699P (PMFX4 BOX ASSY.) & & \\
\hline & $\begin{array}{l}9413 \text { (SCA-775 } \\
\text { SUBASSEMBLY) }\end{array}$ & $\begin{array}{l}\text { INCLUDES TSA \# } 8754 \\
\mathrm{x} 1 \text { (SC-774 BOARD) } \\
\text { AND TSA \#8403AP x } 2 \\
\text { (HHV BOARD) }\end{array}$ & \\
\hline \multicolumn{4}{|c|}{ 8774B POWER PLATE } \\
\hline & 0301C (CAT-5 CABLE, 2') & & \\
\hline & 0360B (POWER CABLE LOT) & & \\
\hline & 0418 (AC LINE FILTER) & & \\
\hline & $\begin{array}{l}\text { 2533A (TERMINAL BLOCK 1(6 } \\
\text { POSITION) }\end{array}$ & & \\
\hline & 2725A (RS-232 TO RS-485) & & \\
\hline & $\begin{array}{l}\text { 3204E (MACHINED } \\
\text { ALUMINUM POWER PLATE) }\end{array}$ & & \\
\hline & $\begin{array}{l}\text { 3450D (POWER SUPPLY } \\
\text { MOUNT) }\end{array}$ & & \\
\hline & $\begin{array}{l}\text { 6463C (15V 5AMP SWITCHING } \\
\text { CHARGER) }\end{array}$ & & \\
\hline & 6661 (SPEED SENSOR KIT) & & $\begin{array}{l}\text { \#6661: SPEED SENSOR KIT } \\
\text { \#6661B: ULTRASONIC } \\
\text { SENSOR }\end{array}$ \\
\hline & 8453B (LD-260B) (\$235.5) & & \#8453: LD-260 \\
\hline \multicolumn{4}{|c|}{ OPTIONAL PARTS } \\
\hline $4804 X 1$ & $\begin{array}{l}\text { 6” X 30" COLLIMATED LEAD } \\
\text { TROUGH }\end{array}$ & & \\
\hline
\end{tabular}




\begin{tabular}{|l|l|l|l|}
\hline TSA Part \# & \multicolumn{1}{|c|}{ Description } & \multicolumn{1}{|c|}{ Comment } & \multicolumn{1}{|c|}{ Recommendation } \\
\hline 6985 & MASTER ENCLOSURE & & \\
& W/BACK PLATE (NEMA 3) & & \#8590: MEDIA \\
\hline $6985 A$ & SLAVE ENCLOSURE W/BACK & & $\begin{array}{l}\text { CONVERTER \#8870A: VD- } \\
580 \text { (COMPLETE) }\end{array}$ \\
& PLATE (NEMA 3) & & \\
\hline
\end{tabular}

Spare parts for the Aspect detection system are presented in Table B.5. The table is divided into major components e.g., detectors, power units, sensor. Physical characteristics are presented in columns 3 and 4 . Parts are separately displayed by Aspect Yantar model number. Table B.6 presents parts for other Aspect subsystems (e.g., telecommunications and video monitoring).

Table B.5. ASPECT Detection Subsystems

\begin{tabular}{|c|c|c|c|c|}
\hline Reference number & Name & $\begin{array}{c}\text { Overall dimensions } \\
(\mathrm{mm})\end{array}$ & $\begin{array}{c}\text { Weight } \\
\text { (kg) }\end{array}$ & $\begin{array}{l}\text { Included into the } \\
\text { monitor, items }\end{array}$ \\
\hline \multicolumn{5}{|l|}{ Cabinets } \\
\hline 301445.018 & Cabinet & 6403703057 & 234 & Yantar-1A \\
\hline $301445.032-02$ & Cabinet & 6403703057 & 234 & Yantar-1A-04X \\
\hline $301445.032-03$ & Cabinet & 6403703057 & 234 & Yantar-1A-04X \\
\hline 418252.002 & Cabinet ShNGK-01 & 10003071735 & 325 & Yantar-1ZH \\
\hline $418252.002-01$ & Cabinet ShNGK-01-01 & 10003071735 & 25 & Yantar-1ZH \\
\hline \multirow[t]{2}{*}{301445.028} & Cabinet & 3005501851 & 121 & Yantar-1P2 \\
\hline & & & & Yantar-2P2 \\
\hline \multicolumn{5}{|l|}{ Gamma detectors } \\
\hline 418223.007 & Scintillation Detecting Unit BDS-G3M & 113015173 & 8.2 & Yantar-2P \\
\hline \multirow[t]{8}{*}{418223.010} & Scintillation Detecting Unit BDS-G6-1 & 109045573,5 & 29 & Yantar-1A \\
\hline & & & & Yantar-1A-04X \\
\hline & & & & Yantar-1P2 \\
\hline & & & & Yantar-1P3 \\
\hline & & & & Yantar-2P2 \\
\hline & & & & Yantar-1U \\
\hline & & & & Yantar-2U \\
\hline & & & & Yantar-PB \\
\hline 418223.017 & Scintillation Detecting Unit BDS-G6-3 & 113015173 & 8.1 & Yantar-1ZH \\
\hline \multicolumn{5}{|l|}{ Neutron detectors } \\
\hline 418249.006 & Neutron Channel Amplifier & 20012260 & 0.8 & Yantar-2P \\
\hline 418249.006-01 & Neutron Channel Amplifier & 20012260 & 0.8 & Yantar-2P \\
\hline 418242.002 & Neutron Counter SN-02 & 3030532 & 0.39 & Yantar-2P \\
\hline 418229.004 & Neutron Detecting Unit & 57222065 & 8.9 & Yantar-2P \\
\hline 418244.136 & Neutron Channel Processing Unit BONK-07 & 2621082 & 0.5 & Yantar-1A-04X \\
\hline \multirow[t]{6}{*}{418244.035} & Neutron Channel Processing Unit BONK-03 & 2617093 & 0.4 & Yantar-1A \\
\hline & & & & Yantar-1ZH \\
\hline & & & & Yantar-1P2 \\
\hline & & & & Yantar-2P2 \\
\hline & & & & Yantar-1U \\
\hline & & & & Yantar-2U \\
\hline $418244.035-01$ & Neutron Channel Processing Unit BONK-03- & 2617093 & 0.4 & Yantar-1P3 \\
\hline
\end{tabular}




\begin{tabular}{|c|c|c|c|c|}
\hline Reference number & Name & $\begin{array}{c}\text { Overall dimensions } \\
(\mathrm{mm})\end{array}$ & $\begin{array}{c}\text { Weight } \\
\text { (kg) }\end{array}$ & $\begin{array}{l}\text { Included into the } \\
\text { monitor, items }\end{array}$ \\
\hline & 01 & & & \\
\hline & & & & Yantar-PB \\
\hline \multirow[t]{9}{*}{412114.003} & Neutron Counter SN-01 & 30301056 & 0.63 & Yantar-1A \\
\hline & & & & Yantar-1A-04X \\
\hline & & & & Yantar-1ZH \\
\hline & & & & Yantar-1P2 \\
\hline & & & & Yantar-1P3 \\
\hline & & & & Yantar-2P2 \\
\hline & & & & Yantar-1U \\
\hline & & & & Yantar-2U \\
\hline & & & & Yantar-PB \\
\hline \multirow[t]{5}{*}{418229.006} & Neutron Detecting Unit BDN-03 & 1130231119 & 18.3 & Yantar-1A \\
\hline & & & & Yantar-1P2 \\
\hline & & & & Yantar-2P2 \\
\hline & & & & Yantar-1U \\
\hline & & & & Yantar-2U \\
\hline \multirow[t]{2}{*}{ 418229.006-01 } & Neutron Detecting Unit BDN-03-01 & 1130231119 & 18.3 & Yantar-1P3 \\
\hline & & & & Yantar-PB \\
\hline 418229.007 & Neutron Detecting Unit BDN-04 & 1086455102 & 31 & Yantar-1ZH \\
\hline 418229.024 & Neutron Detecting Unit BDN-16 & & & Yantar-1A-04X \\
\hline \multicolumn{5}{|c|}{ Controllers and Input-Output units } \\
\hline 426414.001 & Counters Module MSCh & $\begin{array}{l}127201830.195 \\
\text { Yantar-2P }\end{array}$ & & \\
\hline 426449.002 & Counters Power Supply Module MPS & 12540183 & 0.26 & Yantar-2P \\
\hline 426449.001 & Power Supply and Processing Module MPO & 12540183 & 0.26 & Yantar-2P \\
\hline 426449.011 & System Controller Module MSK2 & 12720183 & 0.195 & Yantar-2P \\
\hline 426469.006 & Power Supply and Processing Unit BPO-04 & 70160183 & 1.5 & Yantar-PB \\
\hline 426469.007 & Power Supply and Processing Unit BPO-05 & 80160183 & 2 & Yantar-1ZH \\
\hline $426469.007-01$ & $\begin{array}{l}\text { Power Supply and Processing Unit BPO-05- } \\
01\end{array}$ & 80160183 & 2 & Yantar-1ZH \\
\hline \multirow[t]{7}{*}{$426469.007-03$} & $\begin{array}{l}\text { Power Supply and Processing Unit BPO-05- } \\
03\end{array}$ & 70160183 & 1.5 & Yantar-1A \\
\hline & & & & Yantar-1A-04X \\
\hline & & & & Yantar-1P2 \\
\hline & & & & Yantar-1P3 \\
\hline & & & & Yantar-2P2 \\
\hline & & & & Yantar-1U \\
\hline & & & & Yantar-2U \\
\hline \multirow[t]{4}{*}{426469.010} & Power Supply and Processing Unit BPO-06 & 70160183 & 2 & Yantar-1A \\
\hline & & & & Yantar-1A-04X \\
\hline & & & & Yantar-2P2 \\
\hline & & & & Yantar-2U \\
\hline \multicolumn{5}{|c|}{ Power units and battery } \\
\hline 436234.029 & Module UPS & 120129183 & 1.2 & Yantar-2P \\
\hline \multirow[t]{2}{*}{436234.043} & Module UPS-03 & 120129183 & 0.26 & Yantar-1A \\
\hline & & & & Yantar-1A-04X \\
\hline
\end{tabular}




\begin{tabular}{|c|c|c|c|c|}
\hline Reference number & Name & $\begin{array}{c}\text { Overall dimensions } \\
(\mathrm{mm})\end{array}$ & $\begin{array}{c}\text { Weight } \\
\text { (kg) }\end{array}$ & $\begin{array}{l}\text { Included into the } \\
\text { monitor, items }\end{array}$ \\
\hline & & & & Yantar-1ZH \\
\hline & & & & Yantar-1P2 \\
\hline & & & & Yantar-1P3 \\
\hline & & & & Yantar-2P2 \\
\hline & & & & Yantar-1U \\
\hline & & & & Yantar-2U \\
\hline & & & & Yantar-PB \\
\hline \multirow[t]{10}{*}{000003.001} & Battery BP 12-12 & 1519898 & 4 & Yantar-1A \\
\hline & & & & Yantar-1A-04X \\
\hline & & & & Yantar-1ZH \\
\hline & & & & Yantar-2P \\
\hline & & & & Yantar-PB \\
\hline & & & & Yantar-1P2 \\
\hline & & & & Yantar-1P3 \\
\hline & & & & Yantar-2P2 \\
\hline & & & & Yantar-1U \\
\hline & & & & Yantar-2U \\
\hline \multicolumn{5}{|l|}{ Occupancy sensors } \\
\hline 000001.001 & $\begin{array}{l}\text { Occupancy Sensor Pepperl Fuchs } \\
\text { GD18/GV18/59/102/115 }\end{array}$ & 181539,8 & 0.1 & Yantar-2P \\
\hline \multirow[t]{3}{*}{000001.002} & Occupancy Sensor SPEK-5-75M2 & 65145140 & 1.2 & Yantar-1A \\
\hline & & & & Yantar-1A-04X \\
\hline & & & & Yantar-1ZH \\
\hline 000001.003 & Occupancy Sensor Paradox 460 Paradoor & 40120100 & & Yantar-1P3 \\
\hline \multirow[t]{2}{*}{000001.004} & Photo Electric Sensor SICKWSE 27-3P2430 & 8124,654 & & Yantar-2P2 \\
\hline & & & & Yantar-2U \\
\hline \multirow[t]{3}{*}{000001.005} & Photo Electric Sensor SICKWL 12G-P530 & $55,51541,5$ & 0.12 & Yantar-1P2 \\
\hline & & & & Yantar-1U \\
\hline & & & & Yantar-PB \\
\hline \multirow[t]{3}{*}{000001.006} & Reflector PL80A SICK & 8484 & & Yantar-1P2 \\
\hline & & & & Yantar-PB \\
\hline & & & & Yantar-1U \\
\hline \multirow[t]{10}{*}{000001.009} & Tamper sensor IO & $102-2571010$ & & Yantar-1A \\
\hline & & & & Yantar-1A-04X \\
\hline & & & & Yantar-1ZH \\
\hline & & & & Yantar-1P2 \\
\hline & & & & Yantar-1P3 \\
\hline & & & & Yantar-2P2 \\
\hline & & & & Yantar-1U \\
\hline & & & & Yantar-PB \\
\hline & & & & Yantar-2U \\
\hline & & & & Yantar-2P \\
\hline \multicolumn{5}{|l|}{ Switching boxes } \\
\hline 685169.003 & Switching Board & & & Yantar-PB \\
\hline 685179.004 & Switching Board & 21417655 & & Yantar-2P \\
\hline
\end{tabular}




\begin{tabular}{|c|c|c|c|c|}
\hline Reference number & Name & $\begin{array}{l}\text { Overall dimensions } \\
\text { (mm) }\end{array}$ & $\begin{array}{l}\text { Weight } \\
\text { (kg) }\end{array}$ & $\begin{array}{l}\text { Included into the } \\
\text { monitor, items }\end{array}$ \\
\hline 685179.004-01 & Switching Board & 21417655 & & Yantar-2P \\
\hline 685179.009 & Switching Board & & & Yantar-1ZH \\
\hline 685179.009-01 & Switching Board & & & Yantar-1ZH \\
\hline \multirow[t]{3}{*}{685179.011} & Switching Board & 28018090 & 3.9 & Yantar-1A \\
\hline & & & & Yantar-1A-04X \\
\hline & & & & Yantar-2P2 \\
\hline \multirow[t]{4}{*}{ 685179.011-01 } & Switching Board & 28018090 & 3.9 & Yantar-1A \\
\hline & & & & Yantar-1A-04X \\
\hline & & & & Yantar-2U \\
\hline & & & & Yantar-2P2 \\
\hline \multirow[t]{3}{*}{ 685179.011-02 } & Switching Board & & & Yantar-1P2 \\
\hline & & & & Yantar-1U \\
\hline & & & & Yantar-1P3 \\
\hline \multirow[t]{5}{*}{685624.003} & Junction box & & & Yantar-1A \\
\hline & & & & Yantar-1A-04X \\
\hline & & & & Yantar-1P2 \\
\hline & & & & Yantar-1U \\
\hline & & & & Yantar-1P3 \\
\hline \multirow[t]{2}{*}{$685624.003-02$} & Junction box & & & Yantar-2P2 \\
\hline & & & & Yantar-2U \\
\hline \multicolumn{5}{|l|}{ Alarm units } \\
\hline \multirow[t]{2}{*}{000002.001} & LED Indicator RS N205-729 & 2222 & & Yantar-1A \\
\hline & & & & Yantar-1A-04X \\
\hline \multirow[t]{5}{*}{000002.002} & LED Indicator RS N205-909 & 2222 & & Yantar-1P2 \\
\hline & & & & Yantar-2P2 \\
\hline & & & & Yantar-1U \\
\hline & & & & Yantar-2U \\
\hline & & & & Yantar-PB \\
\hline 000002.003 & LED Indicator RS N211-279 & 2222 & & Yantar-2P \\
\hline \multirow[t]{10}{*}{000002.004} & Sound Alarm RS N626-141 & 505045 & & Yantar-1A \\
\hline & & & & Yantar-1A-04X \\
\hline & & & & Yantar-1ZH \\
\hline & & & & Yantar-1P2 \\
\hline & & & & Yantar-1P3 \\
\hline & & & & Yantar-2P \\
\hline & & & & Yantar-2P2 \\
\hline & & & & Yantar-1U \\
\hline & & & & Yantar-2U \\
\hline & & & & Yantar-PB \\
\hline \multirow[t]{2}{*}{000002.005} & Visual Alarm Delta Design 57100301 & 793121 & & Yantar-1P3 \\
\hline & & & & Yantar-2P \\
\hline 000002.006 & Visual Alarm Delta Design 57100501 & 793121 & & Yantar-1P3 \\
\hline \multirow[t]{3}{*}{000002.007} & Visual Alarm RS N366-1181 & $74,574,538$ & & Yantar-1A \\
\hline & & & & Yantar-1A-04X \\
\hline & & & & Yantar-1P2 \\
\hline
\end{tabular}




\begin{tabular}{|l|l|l|l|l|}
\hline Reference number & Name & $\begin{array}{c}\text { Overall dimensions } \\
(\mathbf{m m})\end{array}$ & $\begin{array}{c}\text { Weight } \\
\mathbf{( k g})\end{array}$ & $\begin{array}{c}\text { Included into the } \\
\text { monitor, items }\end{array}$ \\
\hline & & & & Yantar-2P2 \\
\hline & & & & Yantar-1U \\
\hline & & & & Yantar-2U \\
\hline & & & & Yantar-PB \\
\hline 000002.008 & Visual Alarm RS N366-1197 & & & Yantar-1A \\
\hline & & & & Yantar-1A-04X \\
\hline & & & & Yantar-1P2 \\
\hline & & & & Yantar-2P2 \\
\hline & & & & Yantar-1U \\
\hline & & & & Yantar-2U \\
\hline & & & & \\
\hline PVC & & & & \\
\hline 425681.005 & Control panel PVC-01M & & & All Yantars \\
\hline
\end{tabular}

Table B.6. ASPECT - Other Subsystems

\begin{tabular}{|c|c|c|c|c|}
\hline Function & Subsystem & Reference Number & Weight (kg) & $\begin{array}{l}\text { Included in } \\
\text { Subsystem }\end{array}$ \\
\hline \multirow{25}{*}{$\begin{array}{l}\text { Data acquisition, } \\
\text { processing and } \\
\text { displaying system }\end{array}$} & Operator’s Workstation & ARM-03 & $425681.033-02$ & System unit \\
\hline & & & & Monitor \\
\hline & & & & UPS \\
\hline & & & & Outlet \\
\hline & & & & Printer \\
\hline & & & & Scanner \\
\hline & & & & Keyboard \\
\hline & & & & Mouse \\
\hline & Operator's Workstation & CCD-04 425681.032 & System unit & \\
\hline & & & & Monitor \\
\hline & & & & UPS \\
\hline & & & & Outlet \\
\hline & & & & Printer \\
\hline & & & & Keyboard \\
\hline & & & & Mouse \\
\hline & Data Acquisition Server & DAS-01 & 426681.031 & System unit \\
\hline & & & & Monitor \\
\hline & & & & Switch Ethernet \\
\hline & & & & UPS \\
\hline & & & & Keyboard \\
\hline & & & & Mouse \\
\hline & & & & $\begin{array}{l}\text { Crate with video } \\
\text { servers }\end{array}$ \\
\hline & & & & Mounting cabinet \\
\hline & Database Server & DBS-01 & System unit & \\
\hline & & & & Monitor \\
\hline
\end{tabular}




\begin{tabular}{|c|c|c|c|c|}
\hline \multirow[t]{7}{*}{ Function } & Subsystem & Reference Number & Weight (kg) & $\begin{array}{l}\text { Included in } \\
\text { Subsystem }\end{array}$ \\
\hline & & & & Switch Ethernet \\
\hline & & & & UPS \\
\hline & & & & Keyboard \\
\hline & & & & Mouse \\
\hline & & & & $\begin{array}{l}\text { Crate with SHDSL } \\
\text { modems }\end{array}$ \\
\hline & & & & Mounting cabinet \\
\hline \multirow[t]{23}{*}{$\begin{array}{l}\text { Video Monitoring } \\
\text { System }\end{array}$} & Video monitoring set & $\begin{array}{l}\text { VN-02AC VN-02AC-11 } \\
\text { VN-02AC-21 }\end{array}$ & 424929.010 & Thermo-housing \\
\hline & & & & Video camera \\
\hline & & & & Infra-red search light \\
\hline & & & & Bracket \\
\hline & & & & $\begin{array}{l}\text { Power supply and } \\
\text { commutation unit } \\
\text { BPK-05 }\end{array}$ \\
\hline & & & & Post \\
\hline & & & & Protective post \\
\hline & Video monitoring set & $\mathrm{VN}-02 \mathrm{PC}$ & 424929.008-02 & Thermo-housing \\
\hline & & & & Video camera \\
\hline & & & & Bracket \\
\hline & & & & Switching box \\
\hline & Video monitoring set & VN-02ZhC & 424929.006-01 & Thermo-housing \\
\hline & & & & Video camera \\
\hline & & & & LED search light \\
\hline & & & & $\begin{array}{l}\text { Yantar-1Zh or Yantar- } \\
\text { 2Zh pillar }\end{array}$ \\
\hline & Video monitoring set & VN-02ZhC-IP & 424929.016 & Thermo-housing \\
\hline & & & & Video camera \\
\hline & & & & Light module \\
\hline & & & & Bracket \\
\hline & & & & $\begin{array}{l}\text { Yantar-1Zh or } \\
\text { Yantar-2Zh pillar }\end{array}$ \\
\hline & & & & Anti-vandalism cage \\
\hline & Video monitoring set & VN-04P & 424929.020 & Video camera \\
\hline & & & & Bracket \\
\hline \multirow[t]{11}{*}{$\begin{array}{l}\text { Video Monitoring } \\
\text { System spares }\end{array}$} & Thermo-housing & $\begin{array}{l}\text { GlobalProof CKS- } \\
600+V C+V N\end{array}$ & & \\
\hline & Thermo-housing & SVS-E210 & & \\
\hline & Heater & SINT-KYH.26.01.210 & & \\
\hline & Control unit & SINT-GP.130 & & \\
\hline & Video Camera & Honeywell HZC-755PX & & \\
\hline & Video Camera & Honeywell GC-655P & & \\
\hline & Video Camera & Honeywell HCC-745PTW & & \\
\hline & Video Camera & Axis P1343 & & \\
\hline & Video Camera & Nuvico CV-STD21P & & \\
\hline & Video lens & TG2Z1816AFCS & & \\
\hline & LED search light & PS-3 & & \\
\hline
\end{tabular}




\begin{tabular}{|c|c|c|c|c|}
\hline Function & Subsystem & Reference Number & Weight (kg) & $\begin{array}{l}\text { Included in } \\
\text { Subsystem }\end{array}$ \\
\hline & LED search light & Moscow M1-30 & & \\
\hline & Module & UPS-03 & 436234.043 & \\
\hline & $\begin{array}{l}\text { Storage battery BP12-12 } \\
000003.001\end{array}$ & & & \\
\hline & $\begin{array}{l}\text { Lighting protection } \\
\text { device } 426429.004\end{array}$ & & & \\
\hline & $\begin{array}{l}\text { Lighting protection } \\
\text { device SVP-17 }\end{array}$ & & & \\
\hline & $\begin{array}{l}\text { Video transmitter VSZ- } \\
\text { BNC }\end{array}$ & & & \\
\hline & Video transmitter TWM2 & & & \\
\hline & $\begin{array}{l}\text { Multimedia converter } \\
\text { MOXA EDS-305-S-SC- } \\
\mathrm{T}\end{array}$ & & & \\
\hline \multirow{21}{*}{$\begin{array}{l}\text { Telecommunications } \\
\text { equipment }\end{array}$} & Gateway Modbus/TCP & ADAM-4572 & & \\
\hline & Gateway Modbus/TCP & MOXA Mgate MB3170I & & \\
\hline & Interface repeater & RS-485 BH-01 426441.001 & & \\
\hline & Splitter & RS-485 ICP I-7513 & & \\
\hline & Tamper evident device & BKD-02 425543.004 & & \\
\hline & Power supply unit & TRACO TSL 060-112 & & \\
\hline & Power supply unit & TRACO TSP 140-112 & & \\
\hline & UPS & APC SC6201 & & \\
\hline & Video receiver & Videotronic VZN-1800/19 & & \\
\hline & Power supply unit & Videotronic ST-NT-VZP/19 & & \\
\hline & Video server & AXIS 241Q & & \\
\hline & Video server & AXIS 241Q Blade & & \\
\hline & $\begin{array}{l}\text { Crate with power supply } \\
\text { unit } 19 \text { ” } 1 \mathrm{U}\end{array}$ & $\begin{array}{l}\text { AXIS } 291 \text { 1U Video Server } \\
\text { Rack }\end{array}$ & & \\
\hline & $\begin{array}{l}\text { Crate with power supply } \\
\text { unit } 19 \text { ’3U }\end{array}$ & AXIS Video Server Rack & & \\
\hline & Switch Ethernet, 5 ports & ADAM-6520 & & \\
\hline & Switch Ethernet, 8 ports & EKI-2528 & & \\
\hline & Switch Ethernet, 24 ports & Cisco Catalyst 2960-24TT-L & & \\
\hline & $\begin{array}{l}\text { DSL modem for } \\
\text { dedicated physical lines }\end{array}$ & Zelax M30A & & \\
\hline & $\begin{array}{l}\text { DSL modem for } \\
\text { dedicated physical lines }\end{array}$ & Zelax M1D & & \\
\hline & Media converter & AT-MC 103XL & & \\
\hline & Media converter & MOXA IMC-101-S-SC & & \\
\hline
\end{tabular}




\section{Distribution}

No. of

Copies

\# OFFSITE

1 Project Manager, Sustainability***

NNSA

Address

Washington, D.C. 00000

ATTN: A. Johnston

2 Person**

Organization

Address

City, State Zip

3 Person**

Organization

Address

City, State Zip

ATTN: R. Jim

W. Riggsbee
No. of

\section{Copies}

\section{\# ONSITE}

4 DOE Office of River Protection

Person $1^{*}$

Person $2^{*}$

Person $3^{*}$

5 DOE Richland Operations Office

Person $1^{*}$

Person $2^{*}$

Person 2 (5) A6-38***

Distribution method:

* Email notification of availability at ERICA

** CD

*** Hardcopy 




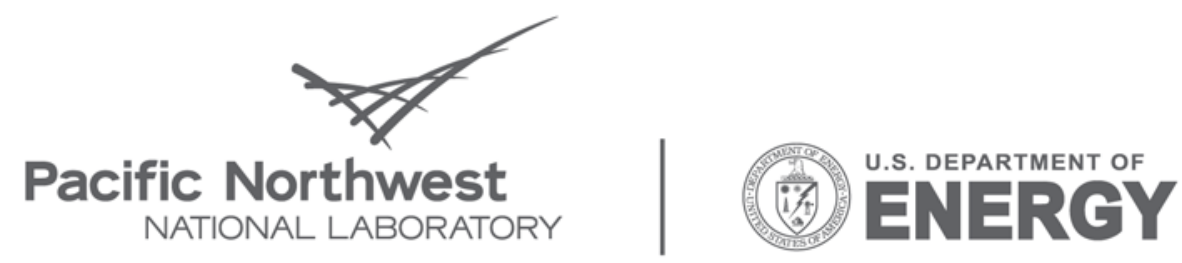

Proudly Operated by Battelle Since 1965

902 Battelle Boulevard

P.O. Box 999

Richland, WA 99352

1-888-375-PNNL (7665)

www.pnl.gov 